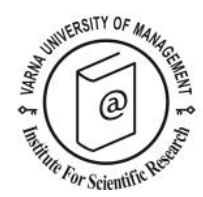

\title{
The relationships between institutionalization and dual commitment: A study on hotel kitchen employees
}

\author{
Emine Şimşek Evren ${ }^{1^{*}}$ and A. Celil Çakıcı ${ }^{2}$
}

\author{
${ }^{1}$ Faculty of Tourism, Department of Tourism Guidance, Gumushane University, Gumushane, Turkey. Email: \\ eminesimsekevren@gmail.com \\ 2 Faculty of Tourism, Mersin University, Mersin, Turkey. E-mail: celilcakici@gmail.com
}

${ }^{*}$ Corresponding author

\begin{abstract}
Long-termed continuance of employees in hotel enterprises, especially in kitchen department where standard production is of utmost importance, is critical for organizational success. At this point, how institutionalization, a phenomenon that is usually associated with standardization, effects the organizational commitment (OC) is an important question. Another important question is how commitment to an impressive supervisor such as the chef mediates the relationship between institutionalization and $\mathrm{OC}$ in institutionalized hotels where standards become important instead of personal approaches. In this context, the relationship between institutionalization, OC, and commitment to the supervisor (CS), which has not been studied before, has been examined within the framework of hotel businesses. The data were collected with an online survey. The sample consisted of the kitchen staff of a national hotel chain in Turkey. The findings demonstrated that the effects of institutionalization on OC and CS were significant. CS partially mediates the relationship between institutionalization and OC. When considered within the scope of the dimensions, the CS has a partial mediating effect on the relationship between cultural power and all three dimensions of OC (affective, continuance, normative). The effect of formalization and professionalization on affective and normative commitment is partially mediated by CS.
\end{abstract}

Keywords: Institutionalization, Dual commitment, Organizational commitment, Commitment to supervisor, Kitchen staff, Chef

Citation: Evren, E.S. and Çakıcı, A.C. (2022). The relationships between institutionalization and dual commitment: A study on hotel kitchen employees European Journal of Tourism Research 31, 3110. 


\section{Introduction}

One of the most critical issues in hotel enterprises in terms of service quality and customer loyalty is consistent services (Akbaba, 2006). Considering the kitchen department, this issue is of particular importance. The customer must be able to eat a meal she/he likes with the same taste every time (Balazs, 2002). In this context, it is possible to state that one of the most important organizational theories for hotel kitchens is institutionalization, which is mostly associated with standardization. Through institutionalization, in businesses that have increased professionalization and formalization and develop a strong organizational culture, practices that differ from person to person or from time to time are replaced by standard quality service production (Apaydın, 2008). Another important aspect in maintaining the service quality standard for hotel businesses and their kitchen department is organizational commitment (OC). Although standard recipes are used in the kitchen department, the individual performances of the cooks affect the quality of the product. Therefore, there is a need for the continuity of employees in kitchen departments to maintain quality standards. The important question in this context is how to ensure personnel continuity in hotel enterprises, which are known to have a high personnel turnover rate, and whether institutionalization has an effect on OC.

Another important issue in terms of the continuity of the staff in the business is the commitment to the supervisor (CS). This commitment is critical, especially in the kitchen department. Because chefs are among the most important department managers in hotel businesses and they have a charismatic effect on their team. Through this effect, he/she creates a loyal team, and sometimes this team even agrees to do more work with less money (Balazs, 2002). Moreover, when the chef starts working in another enterprise, this team follows him/her to change their workplace. In this context, the important question is whether the commitment to a strong/charismatic supervisor (commitment to an individual), such as a chef, mediates the relationship between institutionalization and $\mathrm{OC}$ in institutionalized hotel businesses where standards and procedures are more important than personal practices/preferences of individuals. When the literature is reviewed, it was seen that the relationship between institutionalization, OC and CS has not been previously discussed in either the general organization literature or in the tourism literature. In this context, this study will fill the gap in the literature by examining the said relationship on the data collected from kitchen staff of a national hotel chain in Turkey. Especially, revealing the mediation of the commitment to the chef on the effect of institutionalization on $\mathrm{OC}$ in hotel kitchens points to the importance of the study. It can also be stated that the study will create practical benefits. Hotel managers could find clues regarding how to benefit from the chefs (and other similar supervisors) in the processes of creating institutionalization and OC.

\section{Theory and Hypotheses}

\section{Institutionalization}

Institutionalization is the development of orderly, consistent and socially integrated patterns from irregular and loose organization or technical activities (Selznick, 1996). The most common dimensions of institutionalization include formalization, professionalization, autonomy, transparency/ accountability, cultural power, social responsibility and consistency in the literature. The focus of the present study was on formalization, professionalization and cultural power dimensions, which are considered to be more effective on employees.

Formalization entails the reduction of the uncertainties in the organization and the change from individualized business methods to standardized business methods (Apaydın, 2008; Şen, 2017: 30). Professionalization refers to employment of experts/professionals in institutional positions and determination of the duties, authorities and responsibilities in the organization based on merit 
(Yazıcıoğlu \& Koç, 2009). Cultural power is the acceptance and universal adoption of a business culture in the institution (Apaydın, 2008; Kurt \& Yeșiltaş, 2016; Tavşancı, 2009).

\section{Dual commitment}

In the organizational literature, the issue of commitment is generally discussed based on commitment to the organization. However, there are different types of commitment in business life. Examples are the employee's commitment to the manager, teammates, profession, career and customers. In fact, in organizational/management literature, multiple commitment types have been discussed especially since the 1950s, and after the 1980s, these studies have been quite popular (Cohen, 2003: 192; Wombacher \& Felfe, 2017). In this context, the issue of dual commitment, that entails separation of commitment to the organization and the manager, has been emphasized.

\section{Organizational commitment}

There are several definitions for OC in the literature. OC was described as an individual's attachment to and self-identification with an organization or the psychological commitment of an individual that reflect her or his level of adaptation and internalization of organizational characteristics and objectives (Presbitero, Newman, Le, Jiang, \& Zheng, 2019).

OC is highly based on emotions. The present study was based on the tri-factor classification (affective, continuance, normative) by Allen and Meyer (1990, 1993). Affective commitment is the desire of the employees to keep their jobs willingly. Normative commitment is individual's bond with the organization due to an obligation on the part of the individual. In continuance commitment, employees take into account the cost of quitting their jobs, that is, consider the negative consequences and feel obliged to keep their jobs (Meyer \& Allen, 1997; Bergman, 2006).

\section{Commitment to the supervisor}

The supervisor is a kind of bridge between the organization and the employee, as she or he guides the employees based on the organizational goals. Thus, employees accept their supervisor emotionally and rationally. CS occurs over time (Cheng, Jiang, \& Riley, 2003).

Although it has been addressed with a one-dimensional approach in most studies, CS is multidimensional, similar to OC. Thus, it is possible to approach CS based on three dimensions, namely affective, continuance and normative commitment (Meyer, Morin, \& Vandenberghe, 2015). Affective commitment is associated with the love, self-identification, and bonding of the employee with their supervisor. Normative commitment is the employee's gratitude towards the supervisor. On the other hand, continuance commitment is based on the fact that the employee could not afford to lose her or his benefits that originate in the relationship with the supervisor (Landry \& Vandenberghe, 2009: 8). Previous studies demonstrated that affective commitment, especially to the manager, positively affects high employee performance (Becker, Billings, Eveleth, \& Gilbert, 1996; Becker \& Kernan, 2003; Cheng et al., 2003). In the present study, CS was based on affective commitment.

\section{Relationship between institutionalization and dual commitment}

Institutionalization introduces a system that operates based on certain standards allows the employees to know the institutional reactions to their actions that would be the same for all employees. In other words, institutionalization leads to institutional predictability. This allows the employees to develop the idea that the organization that employs them is fair and reliable (Erdirençelebi, 2012: 196-200). Institutionalized businesses generate trust, especially to their businesses partners, increasing their business volume over time (Apaydın, 2007). Employees work with higher motivation in businesses that 
provide financial security. Thus, it could be suggested that employee satisfaction and commitment would be higher in businesses with financial success due to institutionalization and a fair and reliable organizational system (Adler \& Borys, 1996; Paoline \& Lambert, 2012). Thus, H1 was determined is as follows:

\section{H1. The institutionalization affects organizational commitment.}

Certain studies reported that as the organizational professionalization level increased, the OC of the employees increased as well (Paoline \& Lambert, 2012). Thus, it could be suggested that there is a general correlation between professionalization and OC. So much so that, employees could perceive that they are important in the professional organization and establish affective commitment to the organization. Furthermore, employees may not think about quitting when they live in regions where the number of institutionalized businesses is low, with the concern that employment could not be possible in another professional organization. Thus, they could develop continuance commitment to the organizational. Also, employees who were employed thanks to the professionalization of the business and improved their level of professionalism may not find it moral to leave the organization (Razzak, Jassem, Akter, \& Al Mamun, 2021). Thus, the sub-hypotheses on the relationship between professionalization and OC sub-dimensions were determined as follows:

\section{Hia. Professionalization affects affective commitment to the organization.}

$H_{1}$ b. Professionalization affects continuance commitment to the organization.

H1c. Professionalization affects normative commitment to the organization.

In the literature, there are two views on the effect of formalization on OC. The first is the idea that the creativity of the employees is restricted, employee initiatives are not encouraged, and therefore their OC is reduced in extremely formal organizational structures (Adler \& Borys, 1996). The second is the idea that formalized organizational structures lead to a perception of stability and consistency and improve OC (Organ \& Greene, 1982). Previous studies support both ideas. Certain studies reported a positive correlation between formalization and OC (Lee \& Mathur, 1997) while others including the ones conducted on hotel enterprises (Hartline, Maxham III, \& McKee, 2000) reported negative correlations (Lambert, Paoline, \& Hogan, 2006; Michaels, Dubinsky, Kotabe, \& Lim, 1996). Agarwal (1993) pointed out that in some cultures which are more individualized like US, formalization is assumed as a restricting factor. In this context, it can be stated that the effects of formalization occur in different ways in different cultures. In addition, it can be suggested that the effect of formalization differs depending on the job. For example, Balazs (2002:256) stated that formalization in the kitchen is as important as creativity. At this point, she pointed out that creativity is needed more in the first production phase, and formalization is used in reproduction. In this study, it is suggested that formalization has a positive effect on organizational commitment, based on the idea that it is a phenomenon compatible with Turkish culture, which has both collectivist and individualistic aspects (Ayçiçegi-Dinn \& Caldwell-Harris, 2011), and the kitchen department. Thus, the following hypotheses were proposed.

Hid. Formalization affects affective commitment to the organization.

Hie. Formalization affects continuance commitment to the organization.

Hif. Formalization affects normative commitment to the organization.

Employees in businesses with a strong organizational culture could develop OC. Organization members perceive their organization as an important whole, of which they are a part, and establish an affective 
bond (Gülova \& Demirsoy, 2012). Furthermore, when they quit their jobs (especially in countries with a low corporate institutionalization), they may also feel a continuance commitment to the organization, with the concern of not finding a job in another company with a strong organizational culture. Employees are also likely to develop normative commitment through cultural power, although not as strong as affective and continuance commitment (Ortega-Parra \& Sastre-Castillo, 2013). Especially in businesses with strong organizational culture, employees are firmly committed to organizational culture and may not find it moral to abandon it (Robbins, 1998). Thus, the hypotheses on the effect of cultural power on OC dimensions are determined as follows:

\section{Hig. Cultural power affects affective commitment to the organization.}

Hih. Cultural power affects continuance commitment to the organization.

Hil. Cultural power affects normative commitment to the organization.

Another direct effect investigated in the study was the effect of CS on OC. Studies on this effect generally reported that there were strong correlations between the two variables. Chen, Tsui and Farh (2002) reported positive significant correlations between the CS dimensions (identification with the supervisor, internalizing the values of the supervisor, commitment to the supervisor, extra efforts to benefit the supervisor, attachment to the supervisor) and OC dimensions (value commitment, intention to stay) in a study on service businesses in China. Similarly, Cheng et al. (2003) also found that there were significant correlations between two commitment modes and between these commitment modes and organizational outcomes. Vandenberghe and Bentein (2009), on the other hand, reported strong correlations between CS and OC, especially affective commitment, and CS had a stronger effect on the reduction of staff turnover rate when compared to OC. On the other hand, Vandenberghe, Bentein and Stinglhamber (2004) found that CS had a direct effect on OC, and a direct negative effect on the tendency to quit, both through the mediating effect of OC. Based on these findings, the main and subhypotheses on the effect of CS on OC are determined as follows:

\section{H2. Commitment to the supervisor affects organizational commitment.}

$H_{2}$. Commitment to the supervisor affects affective commitment to the organization.

$\mathrm{H}_{2} b$. Commitment to the supervisor affects continuance commitment to the organization.

H2c. Commitment to the supervisor affects normative commitment to the organization.

Another relationship analyzed in the study was the relationship between institutionalization and CS. Although there is no study on this relationship in the literature, it could be argued that the formal organizational structure induced by institutionalization, professionalization and organizational culture could allow the employees to develop positive emotions and commitment towards their supervisors. In a formal organizational order, the supervisor should make predictable decisions based on the system of rules and procedures (Apaydın, 2008: 123), and this could allow the employees to develop commitment to their supervisor over time. The increase in professionalization, another dimension of institutionalization, could lead to the recruitment of more qualified supervisor and improve the professionalism of the current supervisor (Razzak et al., 2021). In this context, certain studies (Vandenberghe et al., 2004) reported that employees' respect for their supervisor' professional competency increases their commitment to their supervisors. Similarly, the development of a strong organizational culture could increase CS. Supervisors who pioneer the establishment, development and sharing of the organizational culture could improve the harmony among the employees and enable commitment as a part of this culture (Van Vianen, Shen, \& Chuang, 2011: 906-907). Thus, the main and sub-hypotheses for the correlation between institutionalization and CS are determined as follows: 
H3. Institutionalization affects commitment to the supervisor.

$\mathrm{H}_{3}$ a. Professionalization affects commitment to the supervisor.

$\mathrm{H}_{3}$ b. Formalization affects commitment to the supervisor.

H3c. Cultural power affects commitment to the supervisor.

Another claim of the present study was that CS has a mediating effect on the relationship between institutionalization and OC. In this study, the CS refers to the commitment of kitchen staff to the chef. Balazs (2002) pointed out that chefs are organizational designers and have strong charismatic effects on their team. Through these strong effects, chefs gain loyalty of workers, and this loyalty ensures that employees stay in the business for a long time. Certain studies in general business literature also supported this approach. For example, Becker et al. (1996) reported that CS had significant positive effects on employee performance and their loyalty to the company. The important question at this point is that how the commitment to a strong leader such as the chef mediates the effect of institutionalization on organizational commitment in businesses run based on standards rather than individual approaches due to institutionalization. Therefore, the following hypothesis was proposed.

\section{$\mathrm{H}_{4}$. Commitment to the supervisor has a mediating effect on the relationship between institutionalization and organizational commitment.}

In the study, the mediating effect of the dimensions of institutionalization is also emphasized. Professionalization, one of these dimensions, is formed by the high rate of professionals in the organization and the inclusion of these professionals in organizational decision processes. Businesses with a high level of professionalization create a positive image in their environment and increase the performance and organizational commitment of their employees (Apaydın, 2008). Professionalization is also particularly important for hotel businesses, and chefs, who are also professionals, have an important effect on the professionalization of hotels. Chefs, as organizational designers, ensure the employment of professionals in their teams. Also, as educators, they support the professionalization of existing staff (Swift, Malek, \& Swift, 2019; Swift, 2017; Pratten, 2003; Balazs, 2002). In this context, the study focuses on the question of how commitment to a strong professional such as the chef plays a mediating role in the effect of professionalization on OC. Therefore, the following hypotheses are proposed.

$\mathrm{H}_{4} \mathrm{a}$. Commitment to the supervisor has a mediating effect on the relationship between professionalization and affective commitment to the organization.

$H_{4} b$. Commitment to the supervisor has a mediating effect on the relationship between professionalization and continuance commitment to the organization.

$H_{4}$ c. Commitment to the supervisor has a mediating effect on the relationship between professionalization and normative commitment to the organization.

As mentioned above, the relationship between formalization and $\mathrm{OC}$ is relatively complex. While some studies conducted on several sectors reveal that formalization has positive effects on OC (Lambert et al., 2006; Michaels et al., 1996), some mention negative or non-significant effects in some cultures due to the restriction of creativity (Hartline et al., 2000; Lee \& Mathur, 1997; Agarwal, 1993). However, regardless of its effect on organizational commitment, it is a fact that supervisors have important roles in the formation of formalization. For example, supervisors are in a leadership position in determining standards and procedures, which are important parts of formalization, and applying them fairly and effectively. This situation is also valid for hotel enterprises and chefs are among the managers who develop the formalization processes in hotels. Chefs play important roles in the formalization process 
of both the general organization and the kitchen department (Balazs, 2002: 256). At this point, the question of whether the commitment to the supervisor a mediator role in the effect of formalization on OC has is emphasized in the study, and the following hypotheses are proposed.

$H_{4} d$. Commitment to the supervisor has a mediating effect on the relationship between formalization and affective commitment to the organization.

$H_{4}$. Commitment to the supervisor has a mediating effect on the relationship between formalization and continuance commitment to the organization.

$\mathrm{H}_{4} f$. Commitment to the supervisor has a mediating effect on the relationship between formalization and normative commitment to the organization.

One of the outputs of institutionalization is the development of a strong organizational culture (Tavşanc1, 2009: 18) and a strong organizational culture has a positive impact on OC of the employees (Polat \& Meyda, 2011). Undoubtedly, the supervisor has a significant role in the development and diffusion of this culture in the organization (Gürdoğan \& Yavuz, 2013). Thus, the following hypotheses are determined:

$H_{49}$. Commitment to the supervisor has a mediating effect on the relationship between cultural power and affective commitment to the organization.

$\mathrm{H}_{4} \mathrm{~h}$. Commitment to the supervisor has a mediating effect on the relationship between cultural power and continuance commitment to the organization.

$\mathrm{H}_{41}$. Commitment to the supervisor has a mediating effect on the relationship between cultural power and normative commitment to the organization.

The symbolic model based on the above-mentioned hypotheses is presented in Figure 1.

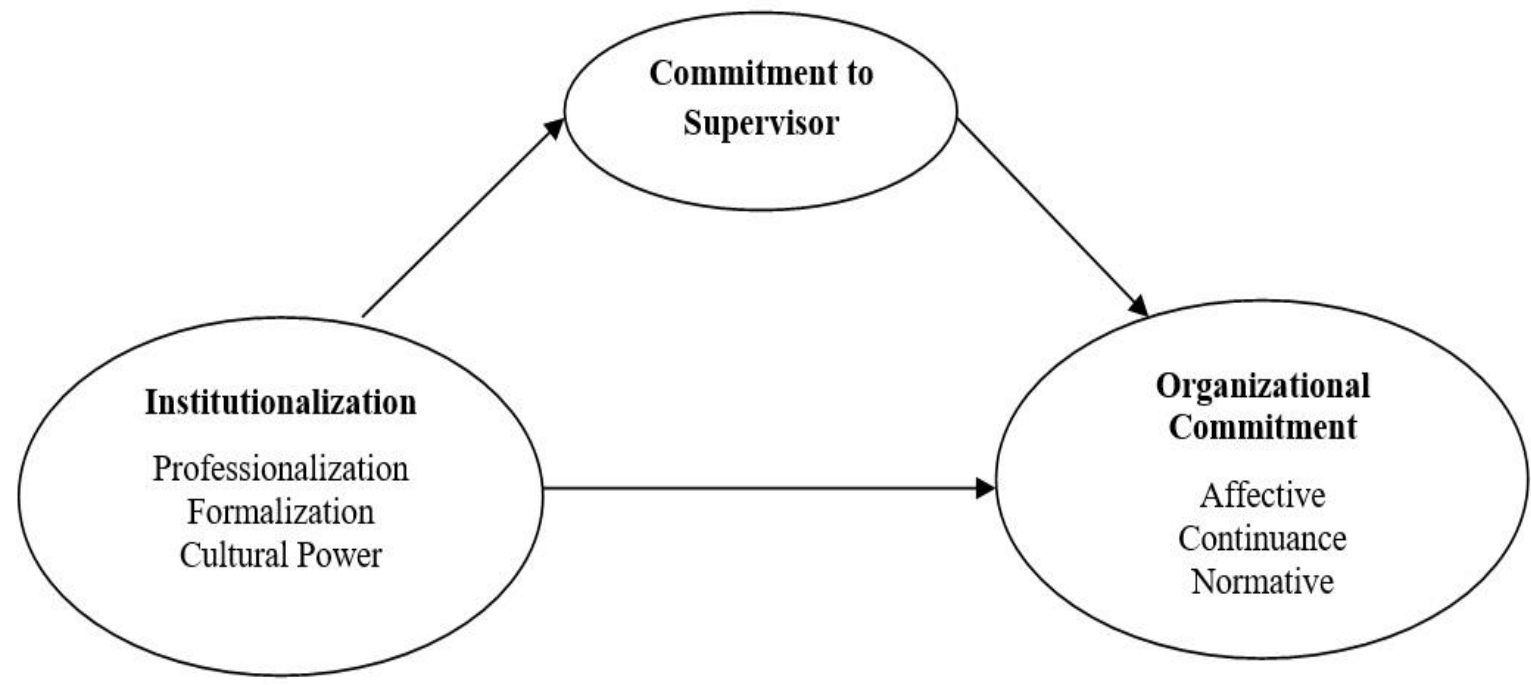

Figure 1. Conceptual Model

\section{Method}

Survey instrument

The study was designed with the correlational survey model, and the study data were collected with a survey form developed based on the literature. The survey included institutionalization and dual 
commitment (OC, CS) scales and demographic questions. Institutionalization was analyzed based on various dimensions including formalization, autonomy, professionalization, cultural power, accountability, social responsibility and consistency in the literature (Apaydın, 2008). Among these dimensions, three (formalization, professionalization and cultural power), which were considered more closely associated with the employees, in other words, had a higher potential to affect employee behavior, were employed in the present study. To measure these three institutionalization dimensions, the reliable and valid scale developed by Apaydin (2007) and employed in institutionalization research in Turkey was used (Zencir, 2013; Kurt \& Yeșiltaș, 2016; Apaydın, 2008).

OC was mostly analyzed based on the three-dimensional structure that includes affective, continuance, and normative commitment developed by Allen and Meyer (1990). In the present study, considering that institutionalization dimensions may be associated with all three types of commitment, the 18 -item scale developed by Meyer, Allen, and Smith's (1993) was preferred. The scale was confirmed for validity and employed in OC studies in various industries (Çöl \& Gül, 2005; Meyer, Stanley, Herscovitch, \& Topolnytsky, 2002), including tourism (Diker, 2014; Yavuz, 2009).

Although the CS has been considered as a multidimensional phenomenon similar to OC in certain studies in the literature (Meyer et al., 2015; Becker et al., 1996), the general trend is that it is onedimensional (Stinglhamber \& Vandenberghe, 2003; Emuwa, 2013; Chughtai, 2013). Thus, the scale developed by Becker et al. (1996) was used. All three scales were scaled based on the 5-point Likert system $(1=$ strongly disagree, $\ldots, 5=$ strongly agree $)$.

\section{Data collection}

The study population included kitchen workers in institutionalized five-star hotel businesses. Assuming that institutionalization is mostly implemented in chain hotels, the study population included the kitchen staff in a Turkish hotel chain ${ }^{1}$, excluding the chefs. The main reason for collecting data from kitchen staff is that chefs are ideal supervisors for measurement of CS, since they have strong effects on their team (Balazs, 2002). In this context, it is an important question in hotel businesses where procedures become more important than individuals' personal preferences with the effect of institutionalization, whether the commitment to an "individual" with a high level of influence like the chef has a mediating effect on the relationship between institutionalization and organizational commitment.

During the interviews conducted with the chain hotel executives, it was determined that there were 132 kitchen employees in 15 hotels that located in 12 different cities, all operational in urban centers, as of March 2019. In the study, it was aimed to collect data from the whole research population (the kitchen staff of the chain) without applying any sampling technique. During the data collection process, first, the necessary permissions were obtained from the top management, then support was requested from the human resources manager responsible for the whole chain. The human resources manager sent the online survey link to all kitchen staff and then asked the chefs to support the process. As a result, 128 out of 132 kitchen workers completed the survey in March-April 2019. Four survey forms were excluded from the data set due to outliers, and the analysis was conducted on the remaining 124 .

\section{The sample characteristics}

The demographic profile of the participants is presented in Table 1. Thus, it was observed that participants were predominantly male, graduated from a high school or lower institution, and their income was $3000 \mathrm{TL}(\sim 367)$ and less. Furthermore, it was determined that most kitchen workers were 44 years old or younger, and the rate of the married and single individuals was similar. 
Table 1. The sample characteristics $(N=124)$

\begin{tabular}{|c|c|c|c|c|c|c|c|}
\hline Variables & Categories & $\mathbf{N}$ & $\%$ & Variables & Categories & $\mathbf{N}$ & $\%$ \\
\hline \multirow{2}{*}{ Gender } & Female & 36 & 29.0 & \multirow{5}{*}{ Education } & Primary school & 29 & 23.4 \\
\hline & Male & 88 & 71.0 & & Middle school & 19 & $15 \cdot 3$ \\
\hline \multirow{2}{*}{ Marital Status } & Married & 63 & 50.8 & & High school & 53 & 42.7 \\
\hline & Single & 60 & 48.4 & & \multirow{2}{*}{$\begin{array}{l}\text { Associate program } \\
\text { Undergraduate } \\
\text { program }\end{array}$} & 9 & $7 \cdot 3$ \\
\hline \multirow{5}{*}{$\begin{array}{l}\text { Income } \\
\text { (Groups were } \\
\text { formed according } \\
\text { to the minimum } \\
\text { wage applicable } \\
\text { for 2019) }\end{array}$} & 2.019 TL and under & 20 & 16.1 & & & 13 & 10.5 \\
\hline & $2.020-2.500 \mathrm{TL}$ & 57 & 46.0 & \multirow{4}{*}{ Age } & 24 and under & 33 & 26.6 \\
\hline & $2.501-3000 \mathrm{TL}$ & 16 & 12.9 & & $25-34$ & 32 & 25.8 \\
\hline & 3.001-4.000 TL & 21 & 16.9 & & $35-44$ & 31 & 25.0 \\
\hline & 4.001 TL and above & 10 & 8.2 & & 45 and above & 28 & 22.6 \\
\hline
\end{tabular}

It could be suggested that the sample reflected the general perception about the kitchen staff in Turkey. Because males are predominant in general commercial kitchens in Turkey and an important number of kitchen staff are without formal professional education. Furthermore, although a small portion of the kitchen staff is well paid, the income level of the majority is at or around the minimum wage.

\section{Analyses}

The data were reviewed before conducting the main analyzes. Thus, initially, outlier analysis was conducted and four survey forms were excluded from the analysis since they were considered outliers. Then, normal distribution of the data, a prerequisite for parametric analysis, was determined. The analysis was based on \pm 1.5 skewness (George \& Mallery, 2010; Tabachnick \& Fidell, 2013; McKillup, 2012) and \pm 8 kurtosis values (Kline, 2005: 50). Negative skewness was determined in all scale data. Şencan (2005) reported that negative skewness requires the transformation of negative skewness into positive skewness with first the inverse transformation, and then the square root transformation (in mild skewness) or logarithmic transformation (in moderate skewness) techniques based on the resulting positive skewness level. In the present study, first inverse transformation and then square root transformation techniques were implemented in all three scales and the normal distribution was confirmed. The skewness of the Organizational Commitment Scale (OCS) was between +1.009 and 0.139 after the transformation, between +0.922 and +0.647 in the Commitment to Supervisor Scale (CSS), and between +0.894 and -0.093 in the Institutionalization Scale (IS). Furthermore, kurtosis values of all scales were in the \pm 8 range. In the study, explanatory factor analysis, confirmatory factor analysis, and mediator impact analysis were employed.

\section{Validity}

Exploratory (EFA) and confirmatory factor analyzes (CFA) were employed to determine the construct validity of the scales. In EFA and CFA, a three-dimensional structure that included formalization, professionalization and cultural power was obtained in IS (Apaydın, 2007, 2008). However, an item was removed from the scale due to residual value (4.07> 4.00) in CFA (Hair et al., 2010: 708-711).

In EFA and CFA, a three-dimensional structure (affective, normative and continuance commitment) was determined in the OCS (Meyer et al., 1993). However, while no problems were determined in the CFA, an item was removed from the scale due to overlapping in EFA. In CSS, both factor analyses resulted in a single factor structure. 
Convergent and divergent validity were also analyzed in the study. Thus, AVE (Average Variance Explained), MSV (Maximum Shared Variance), ASV (Average Shared Variance) and CR (Composite Reliability) were included based on the CFA findings. Convergent validity requires greater than 0.5 AVE and greater than AVE and 0.70 CR. Divergent validity requires a MSV smaller than AVE and an ASV smaller than MSV. For divergent validity, the square root of the AVE should also be greater than the variance shared by the dimension with other dimensions (Yaşlığlu, 2017).

Table 2. Convergent and divergent validity values of the scales

\begin{tabular}{llllllll}
\hline \multirow{2}{*}{ Criteria } & \multicolumn{3}{c}{ Institutionalization } & \multicolumn{3}{c}{ Organizational commitment } & Commitment to \\
\cline { 2 - 7 } & FRML & PRF & CP & NC & CC & AC & supervisor \\
\hline AVE & 0.760 & 0.649 & 0.717 & 0.674 & 0.582 & 0.552 & 0.752 \\
MSV & 0.366 & 0.523 & 0.523 & 0.540 & 0.540 & 0.444 & - \\
ASV & 0.304 & 0.448 & 0.386 & 0.492 & 0.388 & 0.340 & - \\
CR & 0.927 & 0.916 & 0.902 & 0.859 & 0.892 & 0.925 & 0.964 \\
\hline
\end{tabular}

FRML=Formalization; $\mathrm{PRF}=$ Professionalization; $\mathrm{CP}=$ Cultural Power;

$\mathrm{AC}=$ Affective Commitment; $\mathrm{CC}=$ Continuance Commitment, $\mathrm{NC}=$ Normative Commitment

The scale convergent-divergent validity is presented in Table 2. Accordingly, AVE in all scales were greater than 0.50 and $C R$ were greater than 0.70 . CR were also greater than AVE. Thus, the findings demonstrated a strong evidence for convergent validity for all scales. A CR greater than 0.70 indicates that the scales were also reliable.

It was observed that the condition $\mathrm{ASV}<\mathrm{MSV}<\mathrm{AVE}$ was established for all dimensions to determine divergent validity. Furthermore, it was calculated that the square root of the AVE was greater than the correlation values between the dimensions in all dimensions. Thus, it was determined that there was divergent validity.

\section{Reliability}

The overall Cronbach Alpha reliability coefficients of the three scales are quite high (IS=0.933; $\mathrm{OCS}=0.942 ; \mathrm{CSS}=0.930$ ). In addition, item-total correlations of the items also show that the reliability of the scales is high (the lowest item-total correlation for IS=0.571>0.25; OCS $=0.474>0.25$; $\mathrm{CSS}=0.716>0.25)$.

\section{Findings}

Factor structures of the scales

EFA and DFA were conducted to reveal the dimensions of the three scales. Table 3 shows that the IS has three dimensions called cultural power, professionalization and formalization same as the Apaydın's (2008) study. EFA showed the three dimensions explained \%76.4 of the total variance, and these dimensions are reliable. However, in DFA process, one item (There is an information booklet on issues such as safety and working conditions for our employees) was removed from the scale due to its high residual value (4.07>4.00). After removing the item, DFA presented high composite reliability $(>0.70)$ and average variance explained (>0.50), which means that the scale has convergent validity (Hair et al., 2010: 708-711).

Table 3. Factor analyses findings of the IS 


\begin{tabular}{|c|c|c|c|c|c|c|c|c|c|}
\hline \multirow[b]{2}{*}{ Factors } & \multirow[b]{2}{*}{ Items } & \multicolumn{5}{|c|}{ EFA } & \multicolumn{3}{|c|}{ DFA } \\
\hline & & 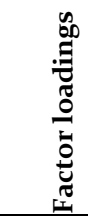 & 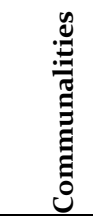 & 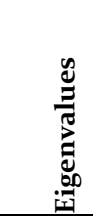 & 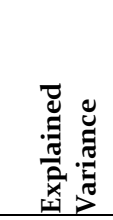 & 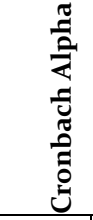 & : & $\sum$ & U \\
\hline 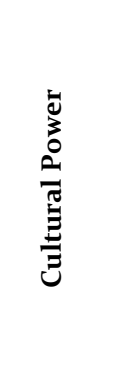 & $\begin{array}{l}\text { 1. It is easy to negotiate even difficult issues among } \\
\text { employees. } \\
\text { 2. There is clear agreement among employees } \\
\text { about the right and wrong ways of working. } \\
\text { 3. There is a strong culture of commitment to the } \\
\text { company among the employees. } \\
\text { 4. There is a good goal alignment among different } \\
\text { departments and different levels (lower/upper) } \\
\text { within our business. } \\
\text { 5. Employees in different departments of our } \\
\text { business share the same corporate perspectives. }\end{array}$ & $\begin{array}{l}0.825 \\
0.824\end{array}$ & $\begin{array}{l}0.764 \\
0.691\end{array}$ & 4.450 & 29.664 & 0.925 & $\begin{array}{l}0.854 \\
0.816 \\
0.890 \\
0.842 \\
0.831\end{array}$ & 0.717 & 0.902 \\
\hline 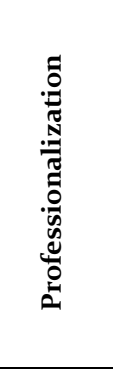 & $\begin{array}{l}\text { 6. Employees are rewarded according to their } \\
\text { ability to do the job and their abilities. } \\
\text { 7. Employees are promoted according to their } \\
\text { ability to do the job and their abilities. } \\
\text { 8. There is specialization in our business. } \\
\text { 9. Professionals have a say in the adoption of new } \\
\text { policies. } \\
\text { 10. Professionals have a say in determining new } \\
\text { recruits. } \\
\text { 11. Our business is professional. }\end{array}$ & $\begin{array}{l}0.850 \\
0.750 \\
0.688 \\
0.625 \\
0.610 \\
0.596\end{array}$ & $\begin{array}{l}0.797 \\
0.701 \\
0.752 \\
0.767 \\
0.696 \\
0.630\end{array}$ & 3.609 & 24.062 & 0.915 & $\begin{array}{l}0.676 \\
0.679 \\
0.887 \\
0.858 \\
0.869 \\
0.836\end{array}$ & 0.649 & 0.916 \\
\hline 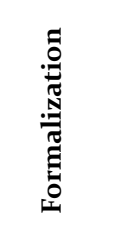 & $\begin{array}{l}\text { 13. There are written operation instructions for } \\
\text { employees in our business. } \\
\text { 14. There are written job descriptions in our } \\
\text { business. } \\
\text { 15. There is an information booklet on issues such } \\
\text { as safety and working conditions for our } \\
\text { employees. }\end{array}$ & $\begin{array}{l}0.838 \\
0.831\end{array}$ & $\begin{array}{l}0.854 \\
0.855\end{array}$ & 3.402 & 22.681 & 0.913 & $\begin{array}{l}0.951 \\
0,970 \\
0,659\end{array}$ & 0.760 & 0.927 \\
\hline
\end{tabular}

DFA Fit Values: $\chi^{2}=153.388(\mathrm{p}=0.000 ; \mathrm{df}=72) \quad \chi^{2} / \mathrm{df}=\mathbf{2 . 1 3} \quad$ RMSEA $=0.096 \quad \mathrm{CFI}=0.947$ TLI $=0.933 \quad$ SRMR=0.052

The fit values obtained with the CFA applied to IS are seen at the bottom of Table $3 . \mathrm{X}^{2}$ statistics should be significant and $\mathrm{x}^{2} / \mathrm{df}$ should be lower than 5 in DFA. The indices should be interpreted within the scope of the number of observed variables and the sample size, and at least one incremental (i.e., CFI or TLI) and one absolute fit index (i.e. GFI, RMSEA, SRMR) must be presented in addition to the $\mathrm{x}^{2}$ statistics. Also, one badness of fit index (i.e. RMSEA, SRMR) and one goodness of fit index (i.e. GFI, CFI, TLI) should be interpreted. The institutionalization scale has 15 items, and the sample size is 124. The RMSEA and SRMR should be lower than 0.8 , and CFI and/or TLI of 0.95 or higher in this circumstance (Hair et al., 2010: 665-678). $\mathrm{X}^{2}$ statistics of the institutionalization scale indicated that the overall fit of the model is good. The goodness of fit indices (GOF), CFI and TLI, include appropriate values which are very close to the cutoff value of 0.95 . The badness of fit indices (BOF), on the other hand, show a little complex structure. The RMSEA value is somewhat higher than the cutoff value (0.096>0.08), while the SRMR value indicates a good fit $(0.052<0.08)$. However, when evaluated in general, it could be concluded that the model fit is appropriate since at least one GOF and one BOF include good values.

Table 4. Factor analyses findings of the $O C$ 


\begin{tabular}{|c|c|c|c|c|c|c|c|c|c|}
\hline \multirow[b]{2}{*}{ 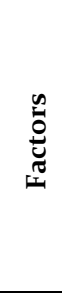 } & \multirow[b]{2}{*}{ Items } & \multicolumn{5}{|c|}{ EFA } & \multicolumn{3}{|c|}{ CFA } \\
\hline & & 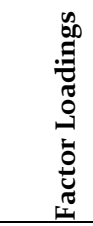 & : & 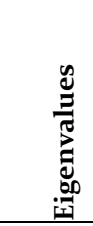 & 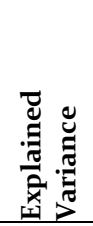 & $\begin{array}{l}\frac{\pi}{2} \\
\frac{1}{2} \\
\frac{1}{0} \\
\frac{\pi}{0} \\
0 \\
0 \\
0\end{array}$ & 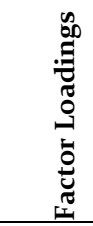 & $\sum^{m}$ & zu \\
\hline 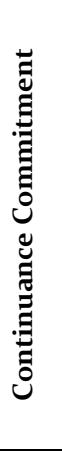 & $\begin{array}{l}\text { 1. It would be very hard for me to leave my organization } \\
\text { right now, even if I wanted to. } \\
\text { 2. I feel that I have too few options to consider leaving } \\
\text { this organization. } \\
\text { 3. Right now, staying with my organization is a matter of } \\
\text { necessity as much as desire. } \\
\text { 4. Too much of my life would be disrupted if I decided I } \\
\text { wanted to leave my organization now. } \\
\text { 5. One of the few negative consequences of leaving this } \\
\text { organization would be the scarcity of available } \\
\text { alternatives. } \\
\text { 6. If I had not already put so much of myself into this } \\
\text { organization, I might consider working elsewhere. }\end{array}$ & $\begin{array}{l}0.843 \\
0.843 \\
0.776 \\
0.709\end{array}$ & $\begin{array}{l}0.792 \\
0.782 \\
0.699 \\
0.684\end{array}$ & 4.334 & 25.5 & 0.874 & $\begin{array}{l}0.815 \\
0.876 \\
0.692 \\
0.85 \\
0.685 \\
0.625\end{array}$ & 0.582 & 0.892 \\
\hline : & $\begin{array}{l}\text { 7. Even if it were to my advantage, I do not feel it would } \\
\text { be right to leave my organization now. } \\
8 \text {. I do not feel any obligation to remain with my current } \\
\text { employer. (R) } \\
\text { 9. This organization deserves my loyalty. } \\
\text { 10. I would feel guilty if I left this organization now. } \\
\text { 11. I would not leave my organization right now because I } \\
\text { have a sense of obligation to the people in it. } \\
\text { 12. I owe a great deal to my organization. }\end{array}$ & $\begin{array}{l}0.762 \\
0.722 \\
0.719 \\
0.693 \\
0.640\end{array}$ & $\begin{array}{l}0.643 \\
0.736 \\
0.815 \\
0.782 \\
0.668\end{array}$ & 4.154 & 24.44 & 0.892 & $\begin{array}{l}0.847 \\
0.683 \\
0.824 \\
0.916 \\
0.871 \\
0.765\end{array}$ & o.674 & 0.859 \\
\hline : & $\begin{array}{l}\text { 13. I do not feel like part of the family at my organization. } \\
\text { (R) } \\
\text { 14. I do not feel a strong sense of belonging to my } \\
\text { organization. (R) } \\
\text { 15. I do not feel emotionally attached to this } \\
\text { organization. (R) } \\
\text { 16. I really feel as if this organization's problems are my } \\
\text { own. } \\
\text { 17. I would be very happy to spend the rest of my career } \\
\text { with this organization. }\end{array}$ & $\begin{array}{l}0.776 \\
0.652 \\
0.629\end{array}$ & $\begin{array}{l}0.688 \\
0.631 \\
0.716\end{array}$ & 3.408 & 20.05 & 0.926 & $\begin{array}{l}0.626 \\
0.665 \\
0.743 \\
0.787 \\
0.868\end{array}$ & $0.55^{2}$ & 0.925 \\
\hline
\end{tabular}

DFA Fit Values: $\chi^{2}=\mathbf{2 2 0 , 1 7}(\mathrm{p}=0.000 ; \mathrm{df}=113) \chi^{2} / \mathrm{df}=1,948 \quad \mathrm{RMSEA}=0.088 \quad \mathrm{CFI}=0.931$ TLI=0.917 SRMR=0.0535

Results of EFA conducted on the OCS showed that it has three dimensions (continuance, normative and affective commitment) same as in the study of Meyer and Allen (1993). However, one item (This institution means great personal meaning to me) was removed from the scale due to the overlapping factor loadings $(>1)$. After removing the item, three dimensions explained \%69.9 of the total variance with very high Cronbach Alpha values (Table 4 ). DFA was conducted on the remaining 17 items and presented that three dimensions have high composite reliability $(>0.70)$ and average variance explained (>0.50). In this context, it's found that three-dimensional structure of OCS has convergent validity (Hair et al., 2010). The DFA cutoff values aforementioned for IS are also valid for OCS since it has 18 items within the scope of the same sample size. $\mathrm{X}^{2}$ statistics of the OCS indicate that the overall fit of the model is good (Table 4 ). The goodness of fit indices (CFI, TLI) are very close to the cutoff values. The badness of fit indices (RMSEA, SRMR) are also acceptable. Overall, it could be interpreted that the 
model fit is appropriate since most of the indices are very close to the cutoff values (Hair et al., 2010: 665-678).

Table 5. Factor analyses findings of the CS

\begin{tabular}{|c|c|c|c|c|c|c|c|c|c|}
\hline \multirow[b]{2}{*}{ Factor } & \multirow[b]{2}{*}{ Items } & \multicolumn{5}{|c|}{ EFA } & \multicolumn{3}{|c|}{ CFA } \\
\hline & & 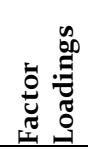 & $\dot{\Xi}$ & 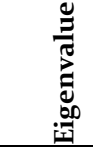 & 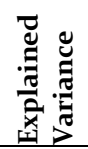 & 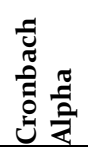 & 总 & $\sum$ & 艺 \\
\hline \multirow{5}{*}{ 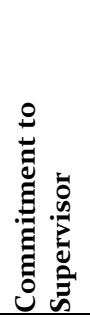 } & $\begin{array}{l}\text { 1. When someone praises my chef, it feels like a personal } \\
\text { compliment to me. }\end{array}$ & 0.943 & 0.889 & \multirow{5}{*}{4.000} & \multirow{5}{*}{80.00} & \multirow{5}{*}{0.93} & $0.95^{2}$ & \multirow{5}{*}{$0.75^{2}$} & \multirow{5}{*}{0.964} \\
\hline & 2. I feel a sense of "ownership" for my chef. & 0.913 & 0.834 & & & & 0.900 & & \\
\hline & $\begin{array}{l}\text { than "he/she". } \\
\text { 4. When someone criticizes my chef, it feels like a }\end{array}$ & 0.905 & 0.819 & & & & 0.867 & & \\
\hline & personal insult. & 0.879 & 0.772 & & & & 0.843 & & \\
\hline & 5. My chef's successes are my successes. & 0.829 & 0.687 & & & & 0.763 & & \\
\hline
\end{tabular}

DFA Fit Values: $\chi^{2}=8.689(\mathrm{p}=0.000 ; \mathrm{df}=5) \quad \chi^{2} / \mathrm{df}=1.738 \quad \mathrm{RMSEA}=0.077 \quad \mathrm{CFI}=0.993 \quad \mathrm{TLI}=0.986 \quad$ SRMR=0.018

CFA conducted on CSS which has five items $(n=124)$ revealed that the model fit is good in general (Table 5). The $x^{2}$ statistics are significant and $x^{2} / d f$ is quite lower than 5 . In addition, all the indices indicated that model fit is good. The goodness of fit indices (CFI, TLI) are higher than 0.95, and the badness of fit indices (RMSEA, SRMR) are lower than o.o8 (Hair et al., 2010: 665-678).

Descriptive findings and correlations between the variables

Descriptive statistics demonstrated that employees considered their workplace as highly institutionalized (Table 6). Cultural power is the most prominent dimension of institutionalization followed by formalization and professionalization respectively. The case was similar in OC; the OC perception of kitchen staff was generally quite high and affective commitment was the most prominent dimension. Affective commitment was followed by normative and continuance commitment, respectively. Kitchen workers' commitment to their chef was higher than their OC.

As it presented in Table 6 , there are high $(>0.70)$ or moderate $(>0.50)$ correlations between most of the variables. Only a few variables have low correlations (>0.30) with each other (Rumsey, 2009: 17). Formalization appears to be the variable with the lowest correlations with other variables. Its correlations with all commitment-related variables (OC, CC, NC, CS) except affective commitment is relatively weak. It also correlates with cultural power in low level. In addition, CS has low correlations with professionalization and continuance commitment.

The relationship between institutionalization, OC and CS

The study was designed to determine the correlations between institutionalization and dual commitment. Thus, the direct effect of institutionalization on OC and CS, the direct effect of CS on OC, and the mediating effect of CS on the relationship between institutionalization and OC were analyzed. For this purpose, first the hypotheses regarding main variables were tested, then the hypotheses based on sub-dimensions of institutionalization and OC were tested. When mediation was identified, the Sobel test was employed to check whether the mediation effect was significant.

Table 6. Descriptive findings and correlations between the variables 


\begin{tabular}{|c|c|c|c|c|c|c|c|c|c|c|c|c|}
\hline Variables & $\mathbf{N}$ & Mean & $\begin{array}{l}\text { Std. } \\
\text { Dev. }\end{array}$ & INS & OC & CS & FRM & PRF & $\mathrm{CP}$ & $\mathrm{AC}$ & $\mathrm{CC}$ & NC \\
\hline INS & 124 & 4.13 & 0.6280 & 1 & & & & & & & & \\
\hline OC & 124 & 3.93 & 0.6833 & $0.710^{* *}$ & & & & & & & & \\
\hline CS & 124 & 4.38 & 0.6585 & $0.502^{* *}$ & $0.567^{\star *}$ & & & & & & & \\
\hline FRM & 124 & 4.13 & 0.7752 & $0.743^{* *}$ & $0.476^{* *}$ & $0.305^{* *}$ & & & & & & \\
\hline PRF & 124 & 4.06 & 0.7932 & $0.939^{* *}$ & $0.627^{* *}$ & $0.373^{* *}$ & $0.605^{* *}$ & & & & & \\
\hline $\mathrm{CP}$ & 124 & 4.21 & 0.6269 & $0.876^{* *}$ & $0.705^{* *}$ & $0.596^{* *}$ & $0.491^{* *}$ & $0.728^{* *}$ & & & & \\
\hline AC & 124 & 4.37 & 0.6472 & $0.642^{* *}$ & $0.785^{* *}$ & $0.561^{* *}$ & $0.533^{* *}$ & $0.506^{* *}$ & $0.648^{* *}$ & & & \\
\hline $\mathrm{CC}$ & 124 & 3.52 & 0.8647 & $0.575^{* *}$ & $0.879^{* *}$ & $0.380^{* *}$ & $0.352^{* *}$ & $0.554^{* *}$ & $0.542^{* *}$ & $0.486^{* *}$ & & \\
\hline NC & 124 & 3.98 & 0.8097 & $0.651^{* *}$ & $0.933^{* *}$ & $0.565^{* *}$ & $0.399^{* *}$ & $0.573^{* *}$ & $0.668^{* *}$ & $0.666^{* *}$ & $0.735^{* *}$ & 1 \\
\hline
\end{tabular}

** Correlation is significant at the o.o1 level (2-tailed).

INS=Institutionalization, OC=Organizational Commitment, CS=Commitment Supervisor, FRML=Formalization, $\mathrm{PRF}=$ Professionalization, $\mathrm{CP}=\mathrm{Cultural}$ Power, $\mathrm{AC}=\mathrm{Affective}$ Commitment, $\mathrm{CC}=$ Continuance Commitment, $\mathrm{NC}=$ Normative Commitment

In the analysis, the direct effects were analyzed individually (first three stages), then the mediator variable (fourth stage) was included in the analysis model. Finally, the Sobel Test results were reviewed. The effect of institutionalization on $\mathrm{OC}\left(\mathrm{H}_{1}\right)$ and $\mathrm{CS}\left(\mathrm{H}_{3}\right)$, the effect of $\mathrm{CS}$ on $\mathrm{OC}\left(\mathrm{H}_{2}\right)$, and the mediating effect of $\mathrm{CS}\left(\mathrm{H}_{4}\right)$ on the impact of institutionalization on OC are presented in Table 7 and Figure 2 . The first three stages demonstrated the results for the $\mathrm{H}_{1}, \mathrm{H}_{2}$, and $\mathrm{H}_{3}$ hypotheses on the one hand, on the other, they exhibited whether the prerequisites for $\mathrm{H}_{4}$ hypothesis were met. ${ }^{2}$

Table 7. The relationships between institutionalization, OC and CS

\begin{tabular}{llllllll}
\hline Phases & Relationships & $\mathbf{R}^{2}(\mathbf{B})$ & Std. $\mathbf{R}^{2}$ & Std. Error & T value & $\mathbf{P}$ & Result \\
\hline Phase 1 & OC $\leftarrow$ INS & 0.820 & 0.816 & 0.140 & 5.863 & $* *$ & $\mathrm{H}_{1}=$ Supported \\
Phase 2 & OC $\leftarrow$ CS & 0.383 & 0.602 & 0.067 & 5.679 & $* *$ & $\mathrm{H}_{2}=$ Supported \\
Phase 3 & CS $\leftarrow$ INS & 0.906 & 0.587 & 0.178 & 5.089 & $* *$ & $\mathrm{H}_{3}=$ Supported \\
Phase 4 & OC $\leftarrow$ CS & 0.155 & 0.228 & 0.060 & 2.580 & $*$ & $\mathrm{H}_{4}=$ Supported \\
& OC $\leftarrow$ INS & 0.729 & 0.691 & 0.142 & 5.140 & $* *$ & \\
Sobel & OC $\leftarrow$ CS $\leftarrow$ INS & 0.729 & 0.691 & 0.182 & 4.005 & $*$ & \\
\hline
\end{tabular}

$\chi^{2} / \mathrm{df}=2.662 ; \mathrm{RMR}=0.005 ; \mathrm{SRMR}=0.0656 ; \mathrm{GFI}=0.867 ; \mathrm{CFI}=0.935 ; \mathrm{TLI}=0.913 ; \mathrm{RMSEA}=0.116$

OC=Organizational Commitment, INS= Institutionalization, $\mathrm{CS}=$ Commitment Supervisor,

*significant at $0.05 ;{ }^{* *}$ significant at 0.01 


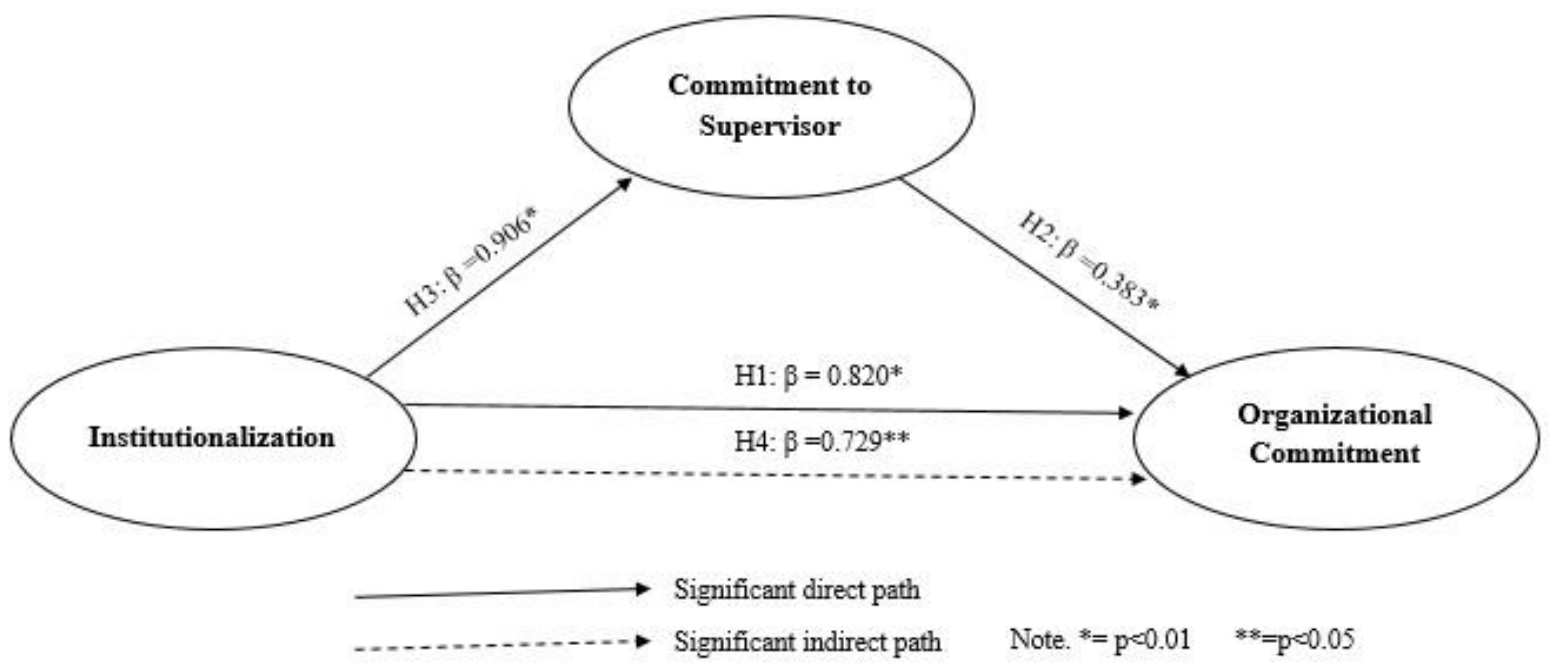

Figure 2. Model 1: The relationships between institutionalization, OC and CS

Based on the findings, institutionalization directly affected OC $(\beta=0.820)$ and CS $(\beta=0.906)$. Furthermore, CS directly affected OC $(\beta=0.383)$. The significance of these three effects also demonstrated that the prerequisites for the mediating effect analysis were met. The analysis of the mediating effect (Stage 4) demonstrated that the effect of institutionalization on OC decreased from $\beta=0.820$ to $\beta=0.729$ due to the mediating role of CS. Thus, since Sobel test findings were also significant, it was determined that CS had a partial mediating role in the effect of institutionalization on OC.

The relationships between professionalization, OC and CS

The direct effect of professionalization on OC dimensions and CS, the impact of the CS on the OC dimensions and the mediating effect of CS on the relationship between professionalization and OC dimensions were analyzed. The findings are presented in Table 8 and Figure 3. Findings demonstrated that professionalization positively affected affective $(\beta=0.583)$, continuance $(\beta=0.470)$, and normative commitment $(\beta=0.578)$. Furthermore, professionalization significantly affected CS $(\beta=0.375)$, and CS significantly affected the three OC dimensions. Thus, it was observed that H1a, H1b, H1c, H2a, H2b, H2c and $\mathrm{H}_{3}$ a hypotheses were supported, and the mediating effect analysis prerequisites were met.

When the mediating factor, CS was added to the model, the affective commitment regression coefficient decreased to $\beta=0.374$, the continuance commitment regression coefficient decreased to $\beta=0.412$, and the normative commitment regression coefficient decreased to $\beta=0.403$. The Sobel Test revealed that the decreases were significant only in affective and normative commitment dimensions. Thus, CS had a partial mediating effect on the relationship between professionalization and affective-normative commitment. Therefore, it could be suggested that although certain fit values were weak, $\mathrm{H}_{4} \mathrm{a}$ and $\mathrm{H}_{4} \mathrm{C}$ hypotheses were supported and $\mathrm{H}_{4} \mathrm{~b}$ hypothesis was not. 
Table 8. The relationships between professionalization, OC and CS

\begin{tabular}{|c|c|c|c|c|c|c|c|}
\hline Phases & Relationships & $\mathbf{R}^{2}(\mathrm{~B})$ & Std. $\mathbf{R}^{2}$ & Std. Error & T value & $\mathbf{P}$ & Result \\
\hline \multirow{3}{*}{ Phase 1} & $\mathrm{AC} \leftarrow \mathrm{PRF}$ & 0.583 & 0.653 & 0.084 & 6.953 & ** & Hia=Supported \\
\hline & $\mathrm{CC} \leftarrow \mathrm{PRF}$ & 0.470 & 0.631 & 0.078 & 6.029 & ** & $\mathrm{H} 1 \mathrm{~b}=$ Supported \\
\hline & $\mathrm{NC} \leftarrow \mathrm{PRF}$ & 0.578 & 0.651 & 0.092 & 6.316 & ** & Hic $=$ Supported \\
\hline \multirow[t]{3}{*}{ Phase 2} & $\mathrm{AC} \leftarrow \mathrm{CS}$ & 0.680 & 0.688 & 0.091 & 7.507 & ** & $\mathrm{H} 2 \mathrm{a}=$ Supported \\
\hline & $\mathrm{CC} \leftarrow \mathrm{CS}$ & 0.346 & 0.408 & 0.084 & 4.127 & ** & $\mathrm{H} 2 \mathrm{~b}=$ Supported \\
\hline & $\mathrm{NC} \leftarrow \mathrm{CS}$ & 0.614 & 0.619 & 0.100 & 6.139 & ** & $\mathrm{H}_{2 \mathrm{c}}=$ Supported \\
\hline Phase 3 & $\mathrm{CS} \leftarrow \mathrm{PRF}$ & 0.375 & 0.423 & 0.081 & 4.630 & ** & $\mathrm{H}_{3} \mathrm{a}=$ Supported \\
\hline \multirow[t]{7}{*}{ Phase 4} & $\mathrm{AC} \leftarrow \mathrm{PRF}$ & 0.374 & 0.425 & 0.075 & 5.006 & ** & \multirow{10}{*}{$\begin{array}{l}\mathrm{H}_{4 \mathrm{a}}=\text { Supported } \\
\mathrm{H}_{4} \mathrm{~b}=\text { Unsupported } \\
\mathrm{H}_{4 \mathrm{C}}=\text { Supported }\end{array}$} \\
\hline & $\mathrm{CC} \leftarrow \mathrm{PRF}$ & 0.412 & 0.553 & 0.079 & 5.21 & $* *$ & \\
\hline & $\mathrm{NC} \leftarrow \mathrm{PRF}$ & 0.403 & $0.45^{8}$ & 0.081 & 4.977 & $* *$ & \\
\hline & $\mathrm{CS} \leftarrow \mathrm{PRF}$ & 0.372 & 0.418 & 0.082 & 4.557 & $* *$ & \\
\hline & $\mathrm{NC} \leftarrow \mathrm{CS}$ & 0.399 & 0.404 & 0.087 & 4.573 & ** & \\
\hline & $\mathrm{CC} \leftarrow \mathrm{CS}$ & 0.128 & 0.153 & 0.075 & 1.713 & 0.087 & \\
\hline & $\mathrm{AC} \leftarrow \mathrm{CS}$ & 0.489 & 0.494 & 0.085 & $5 \cdot 775$ & ** & \\
\hline \multirow[t]{3}{*}{ Sobel Test } & $\mathrm{AC} \leftarrow \mathrm{CS} \leftarrow \mathrm{PRF}$ & 0.182 & 0.207 & 0.063 & 2.889 & $0.001^{*}$ & \\
\hline & $\mathrm{CC} \leftarrow \mathrm{CS} \leftarrow \mathrm{PRF}$ & 0.048 & 0.64 & 0.071 & 0.676 & 0.11 & \\
\hline & $\mathrm{NC} \leftarrow \mathrm{CS} \leftarrow \mathrm{PRF}$ & 0.148 & 0.169 & 0.067 & 2.209 & ** & \\
\hline
\end{tabular}

$\chi^{2}=664.236 ; \mathrm{df}=338 ; \chi^{2} / \mathrm{df}=1.965 ; \mathrm{RMR}=0.011 ; \mathrm{SRMR}=0.1055 ; \mathrm{GFI}=0.739 ; \mathrm{TLI}=0.874 ; \mathrm{CFI}=0.887 ; \mathrm{RMSEA}=0.089$

$\mathrm{CS}=$ Commitment Supervisor, $\mathrm{AC}=$ Affective Commitment, $\mathrm{CC}=$ Continuance Commitment, $\mathrm{NC}=\mathrm{Normative}$ Commitment, $\mathrm{PRF}=$ Professionalization

${ }^{*}$ significant at $0.05 ;{ }^{* *}$ significant at 0.01

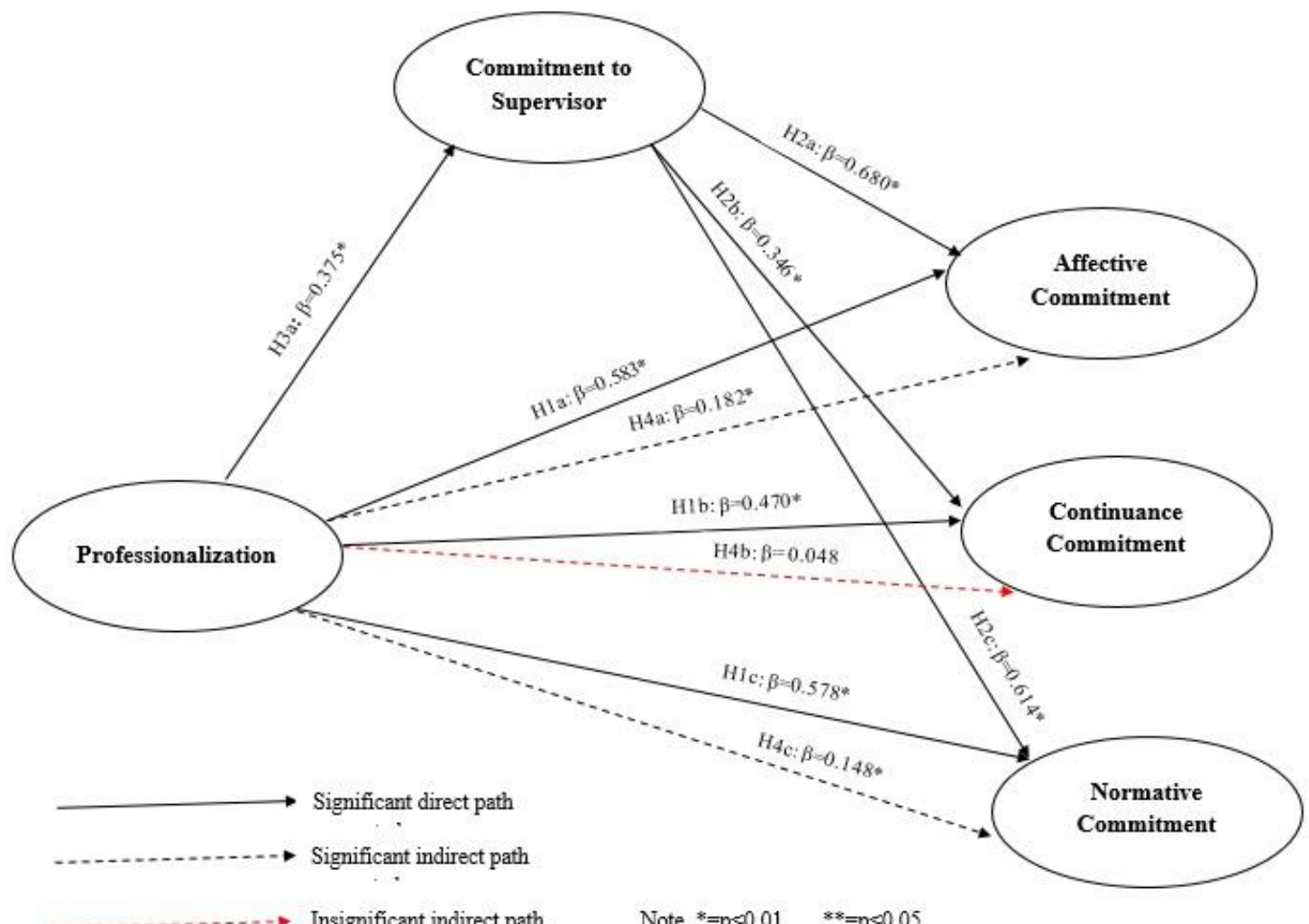

Figure 3. Model 2: The relationships between professionalization, OC and CS 
The relationships between formalization, OC and CS

The test results for the relationships between formalization and dual commitment, another dimension of institutionalization, are presented in Table 9 and Figure 4 . It was determined that formalization had a significant impact on affective $(\beta=0.516)$, continuance $(\beta=0.267)$, and normative commitment $(\beta=0.434)$ and $C S(\beta=0.338)$. Thus, H1d, H1e, Hif and $\mathrm{H}_{3}$ b hypotheses were supported. It was also determined that the requirements for mediation tests were met. Therefore, the mediating effect was analyzed by including the CS in the model.

Table 9. The relationships between formalization, OC and CS

\begin{tabular}{|c|c|c|c|c|c|c|c|}
\hline Phases & Relationships & $\mathbf{R}^{2}(\mathbf{B})$ & Std. $\mathbf{R}^{2}$ & Std. Error & T value & $\mathbf{P}$ & Result \\
\hline \multirow[t]{3}{*}{ Phase 1} & $\mathrm{AC} \leftarrow \mathrm{FRML}$ & 0.516 & 0.624 & 0.076 & 6.781 & ** & Hid= Supported \\
\hline & $\mathrm{CC} \leftarrow \mathrm{FRML}$ & 0.267 & 0.376 & 0.070 & 3.840 & ** & H1e $=$ Supported \\
\hline & $\mathrm{NC} \leftarrow \mathrm{FRML}$ & 0.434 & 0.508 & 0.083 & 5.233 & ** & Hif= Supported \\
\hline \multirow[t]{3}{*}{ Phase 2} & $\mathrm{AC} \leftarrow \mathrm{CS}$ & 0.680 & 0.688 & 0.091 & $7 \cdot 507$ & ** & $\mathrm{H} 2 \mathrm{a}=$ Supported \\
\hline & $\mathrm{CC} \leftarrow \mathrm{CS}$ & 0.346 & 0.408 & 0.084 & 4.127 & ** & $\mathrm{H}_{2} \mathrm{~b}=$ Supported \\
\hline & $\mathrm{NC} \leftarrow \mathrm{CS}$ & 0.614 & 0.619 & 0.100 & 6.139 & ** & $\mathrm{H} 2 \mathrm{c}=$ Supported \\
\hline Phase 3 & $\mathrm{CS} \leftarrow \mathrm{FRML}$ & 0.338 & 0.391 & 0.078 & 4.378 & $* *$ & $\mathrm{H}_{3} \mathrm{~b}=$ Supported \\
\hline \multirow[t]{7}{*}{ Phase 4} & $\mathrm{AC} \leftarrow \mathrm{FRML}$ & 0.337 & 0.406 & 0.068 & 4.990 & $* *$ & $\mathrm{H}_{4} \mathrm{~d}=$ Supported \\
\hline & $\mathrm{CC} \leftarrow \mathrm{FRML}$ & 0.179 & 0.248 & 0.071 & 2.515 & $0.012^{*}$ & $\mathrm{H}_{4} \mathrm{e}=$ Supported \\
\hline & $\mathrm{NC} \leftarrow \mathrm{FRML}$ & 0.258 & 0.303 & 0.073 & $3 \cdot 521$ & ** & $\mathrm{H}_{4} \mathrm{f}=$ Supported \\
\hline & $\mathrm{CS} \leftarrow \mathrm{FRML}$ & 0.336 & 0.392 & 0.077 & 4.383 & ** & \\
\hline & $\mathrm{AC} \leftarrow \mathrm{CS}$ & 0.500 & 0.517 & 0.083 & 6.004 & ** & \\
\hline & $\mathrm{CC} \leftarrow \mathrm{CS}$ & 0.250 & 0.297 & 0.085 & 2.951 & $0.003^{*}$ & \\
\hline & $\mathrm{NC} \leftarrow \mathrm{CS}$ & 0.483 & 0.486 & 0.095 & 5.092 & ** & \\
\hline \multirow[t]{3}{*}{ Sobel Test } & $\mathrm{AC} \leftarrow \mathrm{CS} \leftarrow \mathrm{FRML}$ & 0.168 & 0.203 & 0.054 & 3.111 & ** & \\
\hline & $\mathrm{CC} \leftarrow \mathrm{CS} \leftarrow \mathrm{FRML}$ & 0.084 & 0.117 & 0.055 & 1.527 & $0.004^{*}$ & \\
\hline & $\mathrm{NC} \leftarrow \mathrm{CS} \leftarrow \mathrm{FRML}$ & 0.162 & 0.191 & 0.057 & 2.842 & ** & \\
\hline
\end{tabular}

$\chi^{2}=557.235 ; \mathrm{df}=265 ; \chi^{2} / \mathrm{df}=2.103 ; \mathrm{RMR}=0.015 ; \mathrm{SRMR}=0.1397 ; \mathrm{GFI}=0.748 ; \mathrm{CFI}=0.887 ; \mathrm{TLI}=0.872 ; \mathrm{RMSEA}=0.095$

$\mathrm{CS}=$ Commitment Supervisor, $\mathrm{AC}=$ Affective Commitment, $\mathrm{CC}=$ Continuance Commitment, $\mathrm{NC}=$ Normative Commitment; FRML=Formalization. Note: *significant at $0.05 ;{ }^{* *}$ significant at 0.01

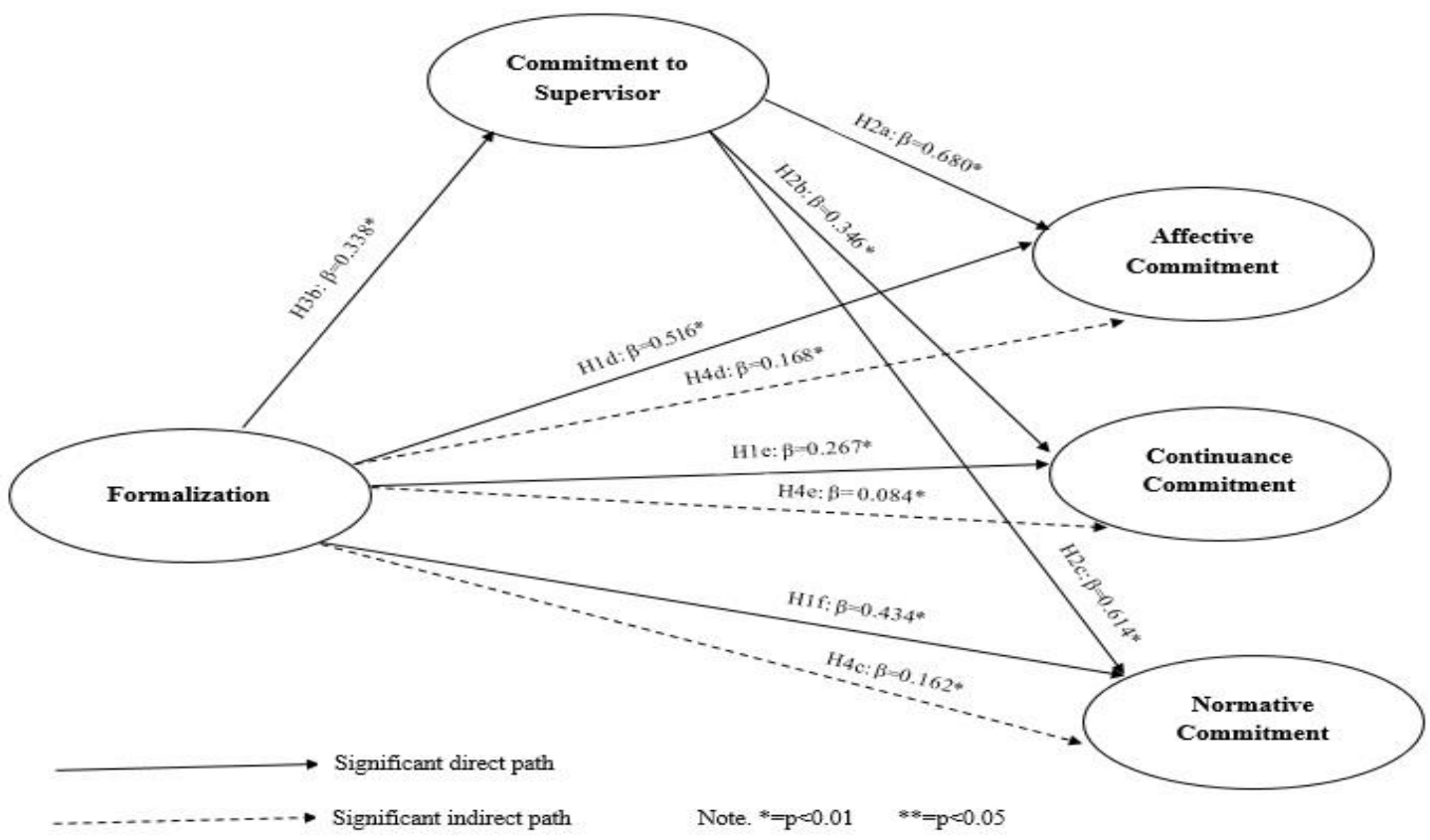

Figure 4. Model 3: The relationships between formalization, OC and CS 
It was observed that the effect of formalization on affective commitment decreased to $\beta=0.337$, the effect on continuance commitment decreased to $\beta=0.179$ and the effect on normative commitment decreased to $\beta=0.258$. Sobel Test demonstrated that the decline, in other words, the mediating effect was significant. Thus, it is determined that the impact of formalization on OC dimensions was partially mediated by $\mathrm{CS}$, and $\mathrm{H}_{4} \mathrm{~d}, \mathrm{H}_{4} \mathrm{e}$ and $\mathrm{H}_{4} \mathrm{f}$ hypotheses were supported. However, it could be argued that the fit of the mediating effect model was relatively weak.

The relationships between cultural power, OC and CS

The findings on the impact of cultural power on OC dimensions and CS, the effect of the CS on OC dimensions, and the mediating effect of the CS on the relationship between cultural power and OC dimensions are presented in Table 10 and Figure 5. It was determined that cultural power significantly and positively affected the affective $(\beta=0.859)$, continuance $(\beta=0.521)$, normative commitment $(\beta=0.779)$ to the organization and CS $(\beta=0.617)$. Furthermore, the effect of CS on the three types of OC was also significant. Thus, Hig, $\mathrm{H}_{1}$, Hii, $\mathrm{H}_{3} \mathrm{c}$ hypotheses were supported and the mediation conditions were met.

Table 10. The relationships between cultural power, OC and CS

\begin{tabular}{llllllll}
\hline Phases & Relationships & $\mathbf{R}^{2}(\mathbf{B})$ & Std. $\mathbf{R}^{2}$ & Std. Error & T value & $\mathbf{P}$ & Result \\
\hline Phase 1 & $\mathrm{AC} \leftarrow \mathrm{CP}$ & 0.859 & 0.812 & 0.098 & 8.780 & $* *$ & Hig=Supported \\
& $\mathrm{CC} \leftarrow \mathrm{CP}$ & 0.521 & 0.615 & 0.091 & 5.723 & $* *$ & Hih=Supported \\
& $\mathrm{NC} \leftarrow \mathrm{CP}$ & 0.779 & 0.767 & 0.112 & 6.972 & $* *$ & H11=Supported \\
\hline Phase 2 & $\mathrm{AC} \leftarrow \mathrm{CS}$ & 0.680 & 0.688 & 0.091 & 7.507 & $* *$ & H2a=Supported \\
& $\mathrm{CC} \leftarrow \mathrm{CS}$ & 0.346 & 0.408 & 0.084 & 4.127 & $* *$ & H2b=Supported \\
& $\mathrm{NC} \leftarrow \mathrm{CS}$ & 0.614 & 0.619 & 0.100 & 6.139 & $* *$ & H2c=Supported \\
\hline Phase 3 & $\mathrm{CS} \leftarrow \mathrm{CP}$ & 0.617 & 0.615 & 0.090 & 6.820 & $* *$ & H3c=Supported \\
\hline Phase 4 & $\mathrm{CS} \leftarrow \mathrm{CP}$ & 0.627 & 0.617 & 0.092 & 6.795 & $* *$ & H4g=Supported \\
& $\mathrm{AC} \leftarrow \mathrm{CP}$ & 0.666 & 0.639 & 0.104 & 6.415 & $* *$ & H4h=Unsupported \\
& $\mathrm{CC} \leftarrow \mathrm{CP}$ & 0.515 & 0.609 & 0.108 & 4.764 & $* *$ & H41=Supported \\
& $\mathrm{NC} \leftarrow \mathrm{CP}$ & 0.648 & 0.642 & 0.115 & 5.655 & $* *$ & \\
& $\mathrm{AC} \leftarrow \mathrm{CS}$ & 0.272 & 0.266 & 0.089 & 3.050 & $0.002^{* *}$ & \\
& $\mathrm{NC} \leftarrow \mathrm{CS}$ & 0.191 & 0.192 & 0.088 & 2.165 & $0.030^{*}$ & \\
& $\mathrm{CC} \leftarrow \mathrm{CS}$ & -0.001 & -0.001 & 0.088 & -0.011 & 0.991 & \\
\hline Sobel Test & $\mathrm{AC} \leftarrow \mathrm{CS} \leftarrow \mathrm{CP}$ & 0.171 & 0.164 & 0.090 & 1.900 & $0.006^{* *}$ & \\
& $\mathrm{CC} \leftarrow \mathrm{CS} \leftarrow \mathrm{CP}$ & -0.001 & -0.001 & 0.099 & -0.010 & 0.99 & \\
& $\mathrm{NC} \leftarrow \mathrm{CS} \leftarrow \mathrm{CP}$ & 0.120 & 0.119 & 0.094 & 1.277 & $0.038^{*}$ & \\
\hline
\end{tabular}

$\chi^{2}=649.602 ; \mathrm{df}=314 ; \chi^{2} / \mathrm{df}=2.069 ; \mathrm{RMR}=0.01 ; \mathrm{SRMR}=0.0979 ; \mathrm{GFI}=0.747 ; \mathrm{TLI}=0.869 ; \mathrm{CFI}=0.883 ; \mathrm{RMSEA}=0.093$ $\mathrm{CP}=$ Cultural Power, $\mathrm{CS}=$ Commitment Supervisor, $\mathrm{AC}=$ Affective Commitment, $\mathrm{CC}=$ Continuance Commitment, $\mathrm{NC}=$ Normative Commitment

*significant at $0.05 ;{ }^{* *}$ significant at 0.01 


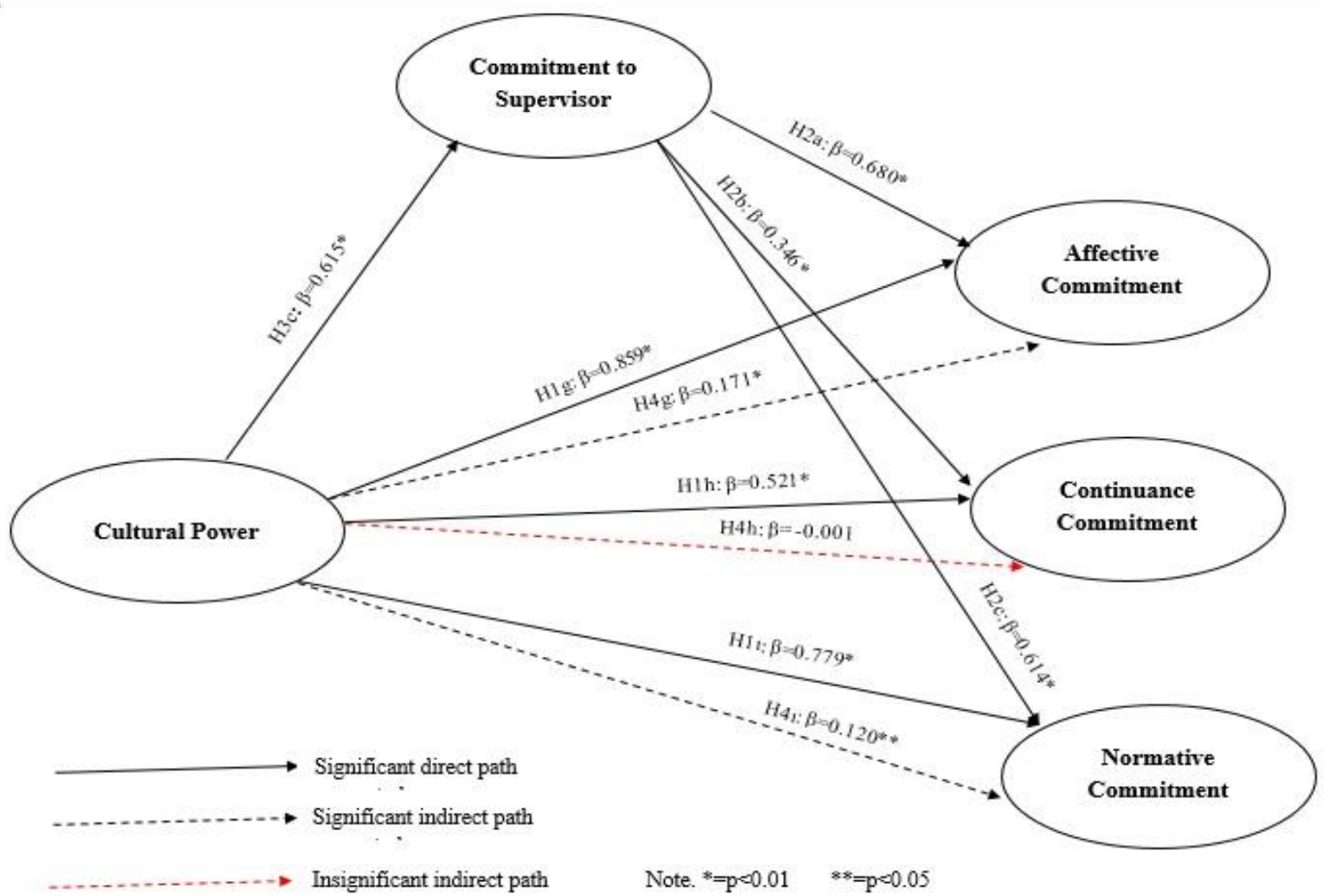

Figure 5. Model 4: The relationships between cultural power, OC and CS

However, when cultural power and CS were included in the model together, the affective commitment regression coefficient decreased to $\beta=0.666$, the continuance commitment coefficient decreased to $\beta=0.515$, and the normative commitment coefficient decreased to $\beta=0.648$. Sobel test revealed that CS played a partial mediating role in the effect of cultural power on affective and normative commitment, while the decrease in continuance commitment was not significant. Thus, $\mathrm{H}_{4} \mathrm{~g}$ and $\mathrm{H}_{4} \mathrm{i}$ hypotheses were supported and $\mathrm{H}_{4} \mathrm{~h}$ hypothesis was not.

\section{Discussion and conclusion}

One of the most important problems in hotel kitchens is personnel turnover. Although meals are prepared with standard recipes, the individual performances of the employees add value to the product and maintain the standard in dishes. Therefore, continuance of employees in hotel enterprises is a critical factor. Furthermore, in departments such as the kitchen where the supervisor (head chef) is of critical importance, both OC and CS should be analyzed. Because the chef is a powerful figure in the kitchen and usually work with their own team, and move between businesses together, especially in Turkey. Thus, what is the mediating effect of commitment to the chef on the impact of institutionalization on $\mathrm{OC}$ in institutionalized hotel businesses that do not depend on individuals but standards, procedures and corporate culture? Based on this basic question, the relationships between institutionalization, OC and CS were investigated. 
The satisfaction of the employees and their long-termed productive working in an enterprise depend largely on the provision of decent work conditions. According to ILO (2020), "decent work involves opportunities for work that is productive and delivers a fair income, security in the workplace and social protection for families, better prospects for personal development and social integration, freedom for people to express their concerns, organize and participate in the decisions that affect their lives and equality of opportunity and treatment for all women and men". Besides, there are several organizational factors (organizational justice, employee empowerment, organizational culture, and climate etc.) that has been discussed in the literature as antecedents of employees' commitment to the organization (Presbitero et al., 2019). In this study, institutionalization was considered as the antecedent of OC. Findings revealed that institutionalization increases the $\mathrm{OC}$ of the kitchen workers in hotel businesses, as hypothesized. This finding was also valid for the dimensions of both institutionalization and OC. All institutionalization dimensions (formalization, professionalization, cultural power) had significant positive effects on all OC dimensions (affective, continuance, and normative). This situation shows that employees' commitment to businesses that standardize their working methods with written rules, attributes importance to professionalization, and develop a strong organizational culture in general, has increased.

Previous studies point out that especially professionalization and cultural power are important tools in creating organizational commitment in many sectors including tourism (Diker, 2014; Gülova \& Demirsoy, 2012; Nikpour, 2017; Paoline \& Lambert, 2012; Sejjaaka \& Kaawaase, 2014). On the other hand, although some studies mention the positive effect of formalization on organizational commitment (Lambert et al., 2006; Michaels et al., 1996), the effect of formalization in some cultures and business including hospitality may become controversial (Hartline et al., 2000; Lee \& Mathur, 1997). It can be stated that formalization is less accepted, especially in more liberal and individualized societies, with the idea that standard business methods will restrict creativity (Agarwal, 1993). The positive effect of formalization in this study can be explained by the fact that standardization and written procedures are important factors in the kitchen (Balazs, 2002) and that the Turks are familiar with standard business procedures since their culture includes more collectivistic less individualistic aspects (Ayçiçegi-Dinn \& Caldwell-Harris, 2011). In this context, the positive effects of cultural power and professionalization on organizational commitment can be generalized to many jobs and cultures, while the effect of formalization should be evaluated in terms of the general cultural structure and specific circumstances of the job.

In the study, it was also determined that institutionalization had a significant effect on the other dimension of dual commitment, CS, based on both main variables and dimensions. Thus, it was found that the commitment of employees in highly professionalized, formalized hotel enterprises with high cultural power to chefs had increased. It was determined that institutionalization was the precursor of OC as well as CS. This finding can be explained within the scope of the roles of supervisors (especially the department managers who are in direct contact with lower-level employees) in the institutionalization processes. For example, the chef is the leader in the process of determining the standard work procedures in the kitchen department. In addition, as an organizational designer, the chef is able to increase the level of professionalism within the kitchen organization by contributing to the professional development of the employees and focusing on professionals in personnel selection. Moreover, the chef has a leadership role in the development of culture in the kitchen organization and promotes the acceptance of the general business culture in the kitchen department (Wan, Hsu, Wong, \& Liu, 2017; Balazs, 2002). Therefore, supervisors who have become one of the architects of institutionalization with their active roles in all these processes, gain the loyalty of their employees in institutionalized enterprises. 
Another direct effect emphasized in the study was the effect of CS on OC. The findings demonstrated that CS had a significant effect on all three types of commitment; as the commitment to the chef increased, the affective, continuance and normative OC of the employees increased as well. Some previous studies also reported that there were positive correlations between OC and CS (Chen et al., 2002; Cheng et al., 2003). In this context, it could be concluded that supervisors in most cases have ability to create OC. However, the kitchens must be evaluated in particular. Most of the chefs are charismatic leaders and they have strong impacts on their team (Balazs, 2002; Pratten, 2003). It is possible for managers with such leadership abilities to gain the loyalty of their employees, and this loyalty may ensure long term continuity of employees in the organization.

In addition to the correlations between institutionalization and the two commitment types, certain mediating effects were also analyzed in the study. The analysis on main variables revealed that CS had a mediating role on the relationship between institutionalization and OC. In other words, employees' attachment with a supervisor such as a chef strengthens the impacts of institutionalization on organizational commitment. However, CS does not moderate the relationship between all the institutionalization dimensions and OC dimensions. For instance, CS has a significant moderating effect on the relationship between formalization and all the three dimensions of OC, while it does not significantly moderate the relationship between professionalization and continuance commitment. CS also does not have a significant moderating effect on the relationship between cultural power and continuance commitment. This result could be explained within the scope of the supervisors' roles in institutionalization processes, again. Chefs are among the architects of the formalization processes and they are also motivating employees to accept these formal structures. Chefs are also among the professionals working to increase the level of professionalization in the organization by training existing employees and focusing on professionals in recruitment (Payne \& Human; Brown, 2003; Balazs, 2002). Moreover, supervisors who have charismatic effects on their teams, such as kitchen chefs, have important roles in development and spread of the organizational culture (Polat \& Meyda, 2011; Gürdoğan \& Yavuz, 2013). In short, in institutionalized enterprises, CS serves as a driving force for the institutionalization tools such as formalization, professionalization, and cultural power to increase organizational commitment (especially affective and normative commitment). The particular situation of continuance commitment could be explained by the fact that, contrary to other types of OC, it entails compulsory OC.

Within the scope of all these evaluations, institutionalization is one of the important management strategies that can be used in hotel businesses to increase the organizational commitment of the employees, and the employees' feeling of commitment to an effective supervisor such as the chef is an important supporting factor in the implementation of this strategy. Establishing standard working processes, increasing the level of professionalism and creating a strong organizational culture enable employees to develop affective, normative and even continuance commitment to the organization. Commitment to the supervisor, on the other hand, supports the effects of these institutionalization tools, especially in creating affective and normative commitment. In this context, it can be stated that benefiting from strong managers such as the chef, who gained the employees' sense of commitment, supports the success of institutionalization to increase organizational commitment in hotel enterprises.

\section{Practical implications}

The results of this study are highly applicable to hotels, especially in Turkey and in other countries with a similar culture. Some managerial suggestions can be made based on the findings of the study. As a basic suggestion, hotel managers could use institutionalization tools (formalization, professionalization, cultural power) to increase employees' commitment to the organization and in 
reducing turnover rate. In addition, they could use the strong effects of supervisors such as the chef on employees to strengthen the institutionalization tools' impact on organizational commitment, especially on affective and normative commitment which are the most important types of commitment for businesses. From this point of view, especially in countries with less individualistic culture, department managers in hotel businesses can be included in the organizational formalization processes and they can be encouraged to create a formal working order within their own department. Also, they can be encouraged to increase the spread of the general organizational culture in the relevant department and to develop a team culture in harmony with the general organizational culture specific to the department. Finally, in line with the general human resources policy of the enterprise, it can be ensured that they focus on professionals in the recruitment of personnel, and they can be encouraged to increase the professional level of the existing personnel with training programs.

\section{Limitation and future research}

The article has some limitations. First, data were collected from only one Turkish hotel chain. Therefore, although the findings reveal the general picture of the relationships examined, cross-cultural generalization of these findings cannot be made. For instance, as the previous studies revealed (Agarwal, 1993; Hartline et al., 2000; Lambert et al., 2006; Lee \& Mathur, 1997), formalization is a factor that has different effects on organizational outcomes in different cultures. Second, in harmony with the purpose of the study, only the kitchen staff of the relevant hotel chain were surveyed. Therefore, although detailed findings of the kitchen organization are reached, the generalization of the findings to other departments is relatively limited. Finally, demographic differences among employees were not considered in the relationships analyzed. Therefore, different managerial suggestions could not be presented for different segments of workers.

Future research could examine cross-cultural differences by doing a similar study on two or more institutionalized chain hotels with different cultural characteristics. Also, in future research, taking into account the perceived leadership styles in different departments, comparisons between departments can be made. Finally, depending on whether the enterprises provide decent work conditions and the demographic differences of the employees, possible differences in the relevant relationships can be examined.

\section{Endnotes:}

${ }^{1}$ The name of the hotel chain is not given as the managers do not allow it.

${ }^{2}$ In the mediation of variable $\mathrm{Z}$ is analyzed in the impact of an independent variable $(\mathrm{X})$ on dependent variable $(\mathrm{Y})$, $\beta$ should be significant in all $X \rightarrow Y ; X \rightarrow Z ; Z \rightarrow Y$ pathways. When one is insignificant, the mediator test is terminated. In other words, the impacts of $\mathrm{X}$ and $\mathrm{Z}$ on $\mathrm{Y}$ are not analyzed simultaneously. If $\beta$ for $\mathrm{X}$ decreases but remains significant when $\mathrm{Z}$ is added to the model, it could be argued that $\mathrm{Z}$ has partial mediating effect. However, if $\beta$ for $\mathrm{X}$ decreases and is insignificant when $\mathrm{Z}$ is added to the model, it could be argued that $\mathrm{Z}$ has full mediating effect. 
Appendix 1. Survey Form (translated form Turkish)

Dear Participant,

The survey in your hand was designed to measure the perceptions of hotel kitchen workers towards their businesses. The data to be obtained will only be used for scientific purposes within the scope of a doctoral dissertation, will not be shared with third parties. You are not required to provide your name. It is extremely important to give correct answers to the questions in terms of reaching the purpose of the research. The response time of the questionnaire is 6 minutes at most. Thank you for your cooperation and contribution. Best regards.
1) Gender:
( ) Male
2) Marital Status:
( ) Married
( ) Female
3) Education level:
( ) Elementary ( ) Secondary
( ) High School ( ) Associate Degree
( ) Graduate Degree
( ) Master's Degree
( ) $\mathrm{PhD}$

4) Monthly income: ( ) Under 2.019 TL

( ) 2.020-2.500 TL

( ) 2.501-3000 TL

5) Age:
( ) 3.001-4.000 TL
( ) Above 4.001 TL

6) Please indicate how much you agree with the statements about the hotel you work for.

\section{Strongly Disagree $\quad$ Disagree $\quad$ Neither Agree nor Disagree $\quad$ Agree $\quad$ Strongly Agree

1

3

4

5

\section{The statements}

1. It would be very hard for me to leave my organization right now, even if I wanted to.

2. I feel that I have too few options to consider leaving this organization.

3. Right now, staying with my organization is a matter of necessity as much as desire.

4. Too much of my life would be disrupted if I decided I wanted to leave my organization now.

5. One of the few negative consequences of leaving this organization would be the scarcity of available alternatives.

6. If I had not already put so much of myself into this organization, I might consider working elsewhere.

7. Even if it were to my advantage, I do not feel it would be right to leave my organization now.

8. I do not feel any obligation to remain with my current employer. (R)

9. This organization deserves my loyalty.

10. I would feel guilty if I left this organization now.

11. I would not leave my organization right now because I have a sense of obligation to the people in it.

12. I owe a great deal to my organization.

13. This institution means great personal meaning to me.

14. I do not feel like part of the family at my organization. (R)

15. I do not feel a strong sense of belonging to my organization. (R)

16. I do not feel emotionally attached to this organization. (R)

17. I really feel as if this organization's problems are my own.

18 . I would be very happy to spend the rest of my career with this organization.

\begin{tabular}{|l|l|l|l|l|}
\hline \multicolumn{6}{|c|}{ Responses } \\
\hline 1 & 2 & 3 & 4 & 5 \\
\hline 1 & 2 & 3 & 4 & 5 \\
\hline 1 & 2 & 3 & 4 & 5 \\
\hline 1 & 2 & 3 & 4 & 5 \\
\hline 1 & 2 & 3 & 4 & 5 \\
\hline 1 & 2 & 3 & 4 & 5 \\
\hline 1 & 2 & 3 & 4 & 5 \\
\hline 1 & 2 & 3 & 4 & 5 \\
\hline 1 & 2 & 3 & 4 & 5 \\
\hline 1 & 2 & 3 & 4 & 5 \\
\hline 1 & 2 & 3 & 4 & 5 \\
\hline 1 & 2 & 3 & 4 & 5 \\
\hline 1 & 2 & 3 & 4 & 5 \\
\hline 1 & 2 & 3 & 4 & 5 \\
\hline 1 & 2 & 3 & 4 & 5 \\
\hline 1 & 2 & 3 & 4 & 5 \\
\hline 1 & 2 & 3 & 4 & 5 \\
\hline 1 & 2 & 3 & 4 & 5 \\
\hline
\end{tabular}

7) Please indicate how much you agree with the following statements about your chef. Strongly Disagree Disagree Neither Agree nor Disagree Agree Strongly Agree

$$
12
$$

2 3

4

5

\begin{tabular}{|l|l|l|l|l|l|}
\multicolumn{1}{|c|}{$\mathbf{4}$} & \multicolumn{3}{|c|}{ Responses } \\
\hline The statements & 1 & 2 & 3 & 4 & 5 \\
\hline
\end{tabular}




\begin{tabular}{|l|l|l|l|l|l|}
\hline 2. I feel a sense of “ownership" for my chef. & 1 & 2 & 3 & 4 & 5 \\
\hline 3. When I talk about my chef, I usually say "we" rather than "he/she". & 1 & 2 & 3 & 4 & 5 \\
\hline 4. When someone criticizes my chef, it feels like a personal insult. & 1 & 2 & 3 & 4 & 5 \\
\hline 5. My chef's successes are my successes. & 1 & 2 & 3 & 4 & 5 \\
\hline
\end{tabular}

8) Please indicate your level of agreement with the following statements regarding the working order in your workplace.

\begin{tabular}{|c|c|c|c|c|c|}
\hline $\begin{array}{cc}\underset{2}{\text { Disagree }} & \text { Neither Agree nor Disagree } \\
& 3\end{array}$ & \multicolumn{5}{|c|}{$\begin{array}{c}\text { Strongly Agree } \\
5\end{array}$} \\
\hline The statements & \multicolumn{5}{|c|}{ Responses } \\
\hline 1. It is easy to negotiate even difficult issues among employees. & 1 & 2 & 3 & 4 & 5 \\
\hline 2. There is clear agreement among employees about the right and wrong ways of working. & 1 & 2 & 3 & 4 & 5 \\
\hline 3. There is a strong culture of commitment to the company among the employees. & 1 & 2 & 3 & 4 & 5 \\
\hline $\begin{array}{l}\text { 4. There is a good goal alignment among different departments and different levels } \\
\text { (lower/upper) within our business. }\end{array}$ & 1 & 2 & 3 & 4 & 5 \\
\hline $\begin{array}{l}\text { 5. Employees in different departments of our business share the same corporate } \\
\text { perspectives. }\end{array}$ & 1 & 2 & 3 & 4 & 5 \\
\hline 6. Employees are rewarded according to their ability to do the job and their abilities. & 1 & 2 & 3 & 4 & 5 \\
\hline 7. Employees are promoted according to their ability to do the job and their abilities. & 1 & 2 & 3 & 4 & 5 \\
\hline 8. There is specialization in our business. & 1 & 2 & 3 & 4 & 5 \\
\hline 9. Professionals have a say in the adoption of new policies. & 1 & 2 & 3 & 4 & 5 \\
\hline 10. Professionals have a say in determining new recruits. & 1 & 2 & 3 & 4 & 5 \\
\hline 11. Our business is professional. & 1 & 2 & 3 & 4 & 5 \\
\hline $\begin{array}{l}\text { 12. There is an information booklet on issues such as safety and working conditions for } \\
\text { our employees }\end{array}$ & 1 & 2 & 3 & 4 & 5 \\
\hline 13. There are written operation instructions for employees in our business. & 1 & 2 & 3 & 4 & 5 \\
\hline 14. There are written job descriptions in our business. & 1 & 2 & 3 & 4 & 5 \\
\hline $\begin{array}{l}\text { 15. There is an information booklet on issues such as safety and working conditions for } \\
\text { our employees. }\end{array}$ & 1 & 2 & 3 & 4 & 5 \\
\hline
\end{tabular}

\section{References}

Adler, P.S. \& Borys, B. (1996). Two types of bureaucracy: Enabling and coercive. Administrative Science Quarterly, 41, 61-89.

Agarwal, S. (1993). Influence of formalization on role stress, organizational commitment, and work alienation of salespersons: A cross-national comparative study. Journal of International Business Studies, 715-739 Fourth Quarter.

Akbaba, A. (2006). Measuring service quality in the hotel industry: A study in a business hotel in Turkey. International Journal of Hospitality Management, 25(2), 170-192.

Allen, N.J. \& Meyer, J.P. (1990). The measurement and antecedents of affective, continuance and normative commitment to the organization. Journal of Occupational Psychology, 63, 1-18.

Allen, N.J. \& Meyer, J.P. (1993). Organizational commitment: Evidence of career stage effects? Journal of Business Research, 26(1), 49-61.

Apaydın, F. (2007). Örgütlerde kurumsallaşma ve adaptif yeteneklerin pazarlama eylemlerine ve örgütsel performansa etkileri [The effects of institutionalization and adaptive capabilities on marketing actions and organizational performance in organizations] (Unpublished Doctoral Dissertation). Gebze Yüksek Teknoloji Enstitüsü, Kocaeli. 
Apaydın, F. (2008). Kurumsallaşmanın küçük ve orta ölçekli işletmelerin performansına etkileri [Effects of institutionalization on the performance of small and medium size firms]. ZKÜ Sosyal Bilimler Dergisi, 4(7), 121-145.

Ayçiçegi-Dinn, A., \& Caldwell-Harris, C. L. (2011). Individualism-collectivism among Americans, Turks and Turkish immigrants to the US. International Journal of Intercultural Relations, 35(1), 9-16.

Balazs, K. (2002). Take one entrepreneur: The recipe for success of France's great chefs. European Management Journal, 20(3), 247-259.

Becker, T.E. \& Kernan, M.C. (2003). Matching commitment to supervisors and organizations to in-role and extra-role performance. Human Performance, 16, 327-348.

Becker, T.E., Billings, R.S., Eveleth, D.M., \& Gilbert, N.L. (1996). Foci and bases of employee commitment: Implications for job performance. Academy of Management Journal, 39, 464-482.

Bergman, M. E. (2006). The relationship between affective and normative commitment: review and research agenda. Journal of Organizational Behavior, 27(5), 645-663.

Brown, B.B. (2003). Employees' organizational commitment and their perceptions of supervisors' relations-oriented and task-oriented leadership behaviors (Unpublished Doctoral Dissertation). Virginia Polytechnic Institute and State University, Virginia.

Chen, Z. X., Tsui, A. S., \& Farh, J. L. (2002). Loyalty to supervisor vs. organizational commitment: Relationships to employee performance in China. Journal of Occupational and Organizational Psychology, 75(3), 339-356.

Cheng, B.S., Jiang, D.Y., \& Riley, J.H. (2003). Organizational commitment, supervisory commitment, and employee outcomes in the Chinese context: Proximal hypothesis or global hypothesis? Journal of Organizational Behavior, 24(3), 313-334.

Chughtai, A.A. (2013). Linking affective commitment to supervisor to work outcomes. Journal of Managerial Psychology, 28(6), 606-627.

Cohen, A. (2003). Multiple commitments in the workplace: An integrative approach. Manhah, NJ: Lawrence Erlbaum Associates, Publisher.

Çöl, G. \& Gül, H. (2005). Kişisel özelliklerin örgütsel bağlılık üzerine etkileri ve kamu üniversitelerinde bir uygulama [Effects of personal characteristics on organizational commitment and an application in public universities]. Atatürk Üniversitesi İktisadi ve İdari Bilimler Dergisi, 19(1), 291-30.

Diker, O. (2014). Algılanan liderlik tarzları, örgüt kültürü ve örgütsel bağlılık ilişkisinin turizm endüstrisinde incelenmesi [Analysis of the relationship between perceived leadership styles, organizational culture and organizational commitment in tourism industry] (Unpublished Doctoral Dissertation). Eskișehir Osmangazi University, Eskişehir.

Emuwa, A. (2013). Authentic leadership: Commitment to supervisor, follower empowerment, and procedural justice climate. Emerging Leadership Journeys, 6(1), 45-65.

Erdirençelebi, M. (2012). Aile işletmelerinde kurumsallaşmanın gerçekleşmesi ile sürdürülebilirliğin sağlanmasında kuşaklar arası farklılıklar [Intergenerational differences in the family businesses at the ensuring sustainability with the realization of institutionalization] (Unpublished Doctoral Dissertation). Selçuk University, Konya.

George, D. \& Mallery, M. (2010). SPSS for windows step by step: A simple guide and reference, 17.o Update (1oa ed.). Pearson, Boston.

Gülova, A.A. \& Demirsoy, Ö. (2012). Örgüt kültürü ve örgütsel bağlılık arasındaki ilişki: Hizmet sektörü çalışanları üzerinde ampirik bir araştırma [The relationship between organizational culture and organizational commitment: an empirical research on employees of service sector]. Business and Economics Research Journal, 3(3), 49-76.

Gürdoğan, A. \& Yavuz, E. (2013). Turizm işletmelerinde örgüt kültürü ve liderlik davranışı etkileşimi: Muğla ilinde bir araștırma [Interaction between organizational culture and leadership behavior in tourism: a research in the province of Muğla]. Anatolia: Turizm Araștırmaları Dergisi, 24(1), 57-69. 
Hair, J. F., Black, W.C., Babin, B. J., \& Anderson, R. E. (2010). Multivariate data analysis: Global perspective. Upper Saddle River, New Jersey: Pearson Education.

Hartline, M. D., Maxham III, J. G., \& McKee, D. O. (2000). Corridors of influence in the dissemination of customer-oriented strategy to customer contact service employees. Journal of Marketing, 64(2), 35-50.

ILO (International Labor Organization) (2020). Decent work, URL: https://www.ilo.org/global/ topics/decent-work/lang--en/index.htm (Accessed on 10.04.2021).

Kline, R. B. (2005). Principles and practice of structural equation modeling. New York, NY: The Guilford Press.

Kurt, S. \& Yeşiltaş, M. (2016). Otel işletmelerinde kurumsallaşma düzeyinin stratejik yönetim araçlarının kullanımı üzerindeki etkisi: Ankara örneği [The effect of level of institutionalization on the usage of strategic management tools at tourism management: Case of Ankara]. Journal of Tourism and Gastronomy Studies, 4(4), 3-19.

Lambert, E.G., Paoline, E.A. \& Hogan, N.L. (2006). Impact of centralization and formalization on satisfaction and commitment. Criminal Justice Studies, 19(1), 23-44.

Landry, G. \& Vandenberghe, C. (2009). Role of commitment to the supervisor, leader-member exchange, and supervisor-based self-esteem in employee-supervisor conflicts. The Journal of Social Psychology, 149(1), 5-28.

Lee, K.S. \& Mathur, A. (1997). Formalization, role stress, organizational commitment, and propensity to leave: A study of Korean industrial salespersons. Journal of Global Marketing, 11(2), 23-42.

McKillup, S. (2012). Statistics explained: An introductory guide for life scientists. United States: Cambridge University Press.

Meyer, J.P. \&. Allen, N.J. (1997). Commitment in the workplace: Theory, research, and application. Thousand Oaks: Sage.

Meyer, J.P., Allen, N.J., \& Smith, C.A. (1993). Commitment to organizations and occupations: Extension and test of a three-component conceptualization. Journal of Applied Psychology, 78(4), 538.

Meyer, J.P., Morin, A.J., \& Vandenberghe, C. (2015). Dual commitment to organization and supervisor: A person-centered approach. Journal of Vocational Behavior, 88, 56-72.

Meyer, J.P., Stanley, D.J., Herscovitch, L., \& Topolnytsky, L. (2002). Affective, continuance, and normative commitment to the organization: A meta-analysis of antecedents, correlates, and consequences. Journal of Vocational Behavior, 61(1), 20-52.

Michaels, R.E., Dubinsky, A.J., Kotabe, M., \& Lim, C.U. (1996). The effects of organizational formalization on organizational commitment and work alienation in US, Japanese and Korean industrial salesforces. European Journal of Marketing, 30(7), 8-24.

Nikpour, A. (2017). The impact of organizational culture on organizational performance: The mediating role of employee's organizational commitment. International Journal of Organizational Leadership, 6, 65-72.

Organ, D. \& Greene, C.N. (1982). The effects of formalization on professional involvement: A compensatory process approach. Administrative Science Quarterly, 26, 237-252.

Ortega-Parra, A. \& Sastre-Castillo, M.Á. (2013). Impact of perceived corporate culture on organizational commitment. Management Decision, 51(5), 1071-1083.

Paoline, E.A. \& Lambert, E.G. (2012). The issue of control in jail: The effects of professionalism, detainee control, and administrative support on job stress, job satisfaction, and organizational commitment among jail staff. American Journal of Criminal Justice, 37(2), 179-199.

Payne, S.C. \& Huffman, A.H. (2005). A longitudinal examination of the influence of mentoring on organizational commitment and turnover. Academy of Management Journal, 48(1), 158-168.

Polat, M. \& Meyda, C.H. (2011). Örgüt kültürü bağlamında güç eğilimi ve örgütsel bağlılık ilișkisinde örgütsel özdeșleșmenin aracılık rolü [The mediating role of organizational identification in the 
relationship between power tendency and organizational commitment in the context of organizational culture]. Atatürk Üniversitesi İktisadi ve İdari Bilimler Dergisi, 25(1), 153-170.

Pratten, J. D. (2003). What makes a great chef? British Food Journal, 105(7), 454-459.

Presbitero, A., Newman, A., Le, H., Jiang, Z., \& Zheng, C. (2019). Organizational commitment in the context of multinational corporations: a critical review and directions for future research. The International Journal of Human Resource Management, 30(1), 188-218.

Razzak, M. R., Jassem, S., Akter, A., \& Al Mamun, S. A. (2021). Family commitment and performance in private family firms: moderating effect of professionalization. Journal of Small Business and Enterprise Development, 28(5), 669-689.

Robbins, S. P. (1998). Organizational behavior: Concepts, controversies, applications. Grundwerk: Prentice-Hall.

Rumsey, D. J. (2009). Statistics II for dummies. John Wiley \& Sons.

Sejjaaka, S.K. \& Kaawaase, T. (2014). Professionalism, rewards, job satisfaction and organizational commitment amongst accounting professionals in Uganda. Journal of Accounting in Emerging Economies, 4(2), 134-157.

Selznick, P. (1996). Institutionalism “old” and “new”. Administrative Science Quarterly, 41(2), 270-277.

Şen, E. (2017). Kurumsallaşma ve kurumsal yönetișim [Institutionalization and corporate governance]. İstanbul: Beta Yayınları.

Şencan, H. (2005). Sosyal ve davranışsal ölçümlerde güvenirlik ve geçerlilik [Reliability and validity in social and behavioral measures]. Ankara: Seçkin Yayıncılık.

Stinglhamber, F. \& Vandenberghe, C. (2003). Organizations and supervisors as sources of support and targets of commitment: A longitudinal study. Journal of Organizational Behavior, 24(3), 251-270.

Swift, D. B. (2017). Leadership styles in the kitchens of American culinary federation certified chefs: A comparison of industry chefs and culinary educators. (Unpublished Doctoral Dissertation). University of La Verne, California.

Swift, D.B, Malek, K., \& Swift, A. (2019). The differences between ACF professional chefs and chef educators: Concern for task versus concern for people. Journal of Hospitality $\mathcal{E}$ Tourism Education, 31(2), 87-98.

Tabachnick, B.G. \& Fidell, L.S. (2013). Using multivariate statistics. United States: Pearson Education.

Tavşancı, S. (2009). Firmalardaki kurumsallaşma düzeyinin rekabet gücüne etkisi üzerine bir araştırma [A research on the effect of institutionalization level on competitiveness in firms] (Unpublished Doctoral Dissertation). Dokuz Eylül University, İzmir.

Van Vianen, A. E., Shen, C. T., \& Chuang, A. (2011). Person-organization and person-supervisor fits: Employee commitments in a Chinese context. Journal of Organizational Behavior, 32(6), 906-926.

Vandenberghe, C. \& Bentein, K. (2009). A closer look at the relationship between affective commitment to supervisors and organizations and turnover. Journal of Occupational and Organizational Psychology, 82(2), 331-348.

Vandenberghe, C., Bentein, K., \& Stinglhamber, F. (2004). Affective commitment to the organization, supervisor, and work group: Antecedents and outcomes. Journal of Vocational Behavior, 64(1), 47-71.

Wan, T. H., Hsu, Y. S., Wong, J. Y., \& Liu, S. H. (2017). Sustainable international tourist hotels: The role of the executive chef. International Journal of Contemporary Hospitality Management, 29(7), 18731891.

Wombacher, J.C. \& Felfe, J. (2017). Dual commitment in the organization: Effects of the interplay of team and organizational commitment on employee citizenship behavior, efficacy beliefs, and turnover intentions. Journal of Vocational Behavior, 102, 1-14.

Yaşlıoğlu, M.M. (2017). Sosyal bilimlerde faktör analizi ve geçerlilik: Keşfedici ve doğrulayıcı faktör analizlerinin kullanılması [Factor analysis and validity in social sciences: Application of exploratory and confirmatory factor analyses]. İstanbul Üniversitesi İșletme Fakültesi Dergisi, 46, 74-85. 
Yavuz, E. (2009). İşgörenlerin dönüşümcü liderlik ve örgütsel bağlılık ile ilgili tutumlarına yönelik bir araştırma [A study on employees' attitudes towards transformational leadership and organizational attachment]. İşletme Araştırmaları Dergisi, (2), 51-69.

Yazıcıoğlu, İ. \& Koç, H. (2009). Aile işletmelerinin kurumsallaşma düzeylerinin belirlenmesine yönelik karşılaștırmalı bir araștırma [A comparative study to determine the institutionalization levels of family businesses]. Selçuk Üniversitesi Sosyal Bilimler Enstitüsü Dergisi, 21, 497-507.

Zencir, E. (2013). Birinci sınıf restoranlarda kurumsallaşma durumunun değerlendirilmesi: Türkiye örneği [Evaluation of institutionalization in world-class restaurants: The case of Turkey] (Unpublished Doctoral Dissertation). Anadolu University, Eskișehir.

Received: 07/02/2021

Accepted: 01/11/2021

Coordinating editor: Berta Ferrer-Rosell 